\title{
Una polémica artística en el entorno de la Aca- demia de Bellas Artes de San Fernando. Fray José de San Juan de la Cruz y José Bejes. Entre el Barroco Castizo y el Barroco Cortesano
}

\author{
René Jesús PAYO HERNANZ \\ José MATESANZ DEL BARRIO \\ Universidad de Burgos
}

\begin{abstract}
RESUMEN. En 1769, el pintor José Bejes remitió un Memorial a la Real Academia de Bellas Artes de San Fernando, poniendo en conocimiento de esta institución las actuaciones desafortunadas del arquitecto carmelita Fray José de San Juan de la Cruz tanto en obras arquitectónicas, de ingeniería como en la ejecución de grabados. Gracias a este Memorial conocemos las tensas relaciones entre estos dos artistas y se amplía el conocimiento de la biografía de Fray José de San Juan de Cruz, mostrándose como este maestro no sólo diseñó importantes edificios sino que fue también un notable grabador.

Palabras clave: Academia de San Fernando, Barroco Castizo, Barroco Cortesano, Burgos, Haro, La Rioja, Navarra, José Bejes, Fray José de San Juan de la Cruz, Sebastián Portu, Roberto Michel, grabados.
\end{abstract}

ABSTRACT. In 1769, the painter José Bejes sent a Memorial to the Royal Academy of Fine Arts of San Fernando, informing the institution of the unfortunate actions of the Carmelite architect Fray José de San Juan de la Cruz in architectural, engineering and implementation of engravings. Thanks to this Memorial we know the strained relations between the two artists and is broadened the knowledge of the artistic biography of Fray José de San Juan de la Cruz, showing as this artist not only designed important buildings but also was an important engraver.

Key words: Academy of San Fernando, Spanish Baroque, Courtly Baroque, Burgos, Haro, La Rioja, Navarra, José Bejes, Fray José de San Juan de la Cruz, Sebastián Portu, Roberto Michel, engravings.

Los años que siguieron a la creación de la Real Academia de Bellas Artes de San Fernando supusieron, sobre todo en determinados ambientes, una confrontación entre algunos maestros vinculados a esta institución que habían optado por el desarrollo de planteamientos estéticos ligados al
Barroco Cortesano o a un incipiente Neoclasicismo y otros que se mantenían fieles al mundo del Barroco Castizo. En algunos casos, estos desencuentros tenían tras de sí no sólo componentes estéticos sino también ciertos celos profesionales o el deseo de arrojar del panorama artístico a algunos 
artistas que aún contaban con el beneplácito y el apoyo de una clientela tradicional. A veces, estas disputas llegaron al seno de la Real Academia de San Fernando que, en la segunda mitad del siglo XVIII, tuvo la vocación de convertirse en la rectora de los caminos a seguir por el arte hispánico. Una de estas disputas fue la que se desarrolló entre el pintor José Bejes y el arquitecto y escultor Fray José de San Juan de la Cruz, que trascendió hasta esta institución y que nos permite, además de reconstruir los distintos ideales estéticos y celos profesionales de los protagonistas, aportar nueva luz sobre la obra de este importe fraile artista.

\section{FRAY JOSÉ DE SAN JUAN DE LA CRUZ EN EL CONTEXTO DEL ARTE ES- PAÑOL DE MEDIADOS DEL SIGLO XVIII}

La importancia de los "frailesarquitectos" durante los siglos XVII y XVIII fue fundamental en la arquitectura española, traspasando el ámbito de las instituciones religiosas a las que se vinculaban, ejecutando numerosas obras para distintos clientes, tanto eclesiásticos como civiles ${ }^{1}$. Con-

\footnotetext{
1 Por su importancia debemos señalar, entre otras, las investigaciones de F. DÍAZ MORENO sobre la obra de Fray Lorenzo de San Nicolás, "Fray Lorenzo de San Nicolás (1593-1679). Precisiones en torno a su biografía y obra escrita", en Anales de Historia del Arte 14, Madrid, 2004, pp. 157-179; las aportaciones de J.M. MUNOZ JIMÉNEZ relativas a Fray Alberto de la Madre de Dios en su libro Fray Alberto de la Madre de Dios, arquitecto (1575-1635); Santander, 1990; las noticias sobre arquitectos jesuitas aportadas por A. RODRÍGUEZ G. DE CeBAllos en su trabajo Bartolomé de Bustamante y los orígenes de la arquitectura jesuítica en España; Instituto de la Compañía de Jesús, Roma, 1967; las contribuciones dadas al conocimiento de la obra de Fray Pedro Martínez por R. J. PAYO HERNANZ en su obra El retablo en Burgos y su comarca durante los siglos XVII y XVIII (2 vols.); Excma. Diputación Provincial de Burgos, Burgos, 1997 y la monografía de P. CANO SANZ, Fray Antonio de San José Pontones. Arquitecto jerónimo del siglo XVIII; C.S.I.C. (Colección Artes y Artistas 61), Madrid, 2005.
}

cepción de la Peña subraya que la consideración de dichos profesionales continuó siendo notable hasta mediados del siglo $\mathrm{XVIII}^{2}$. Generalmente sumaban una importante formación humanística y científica a la práctica del oficio constructivo, cualidades que eran reconocidas por sus propias órdenes, concejos, cabildos y particulares.

Entre los nombres de los "frailesarquitectos" del siglo XVIII destaca el de Fray José de San Juan de la Cruz, perteneciente a la orden del Carmen, que alcanzó una gran proyección y fama en los años centrales de esta centuria. Dicho personaje ejemplifica el relevante papel que jugaron los miembros de su congregación en el ámbito de la arquitectura hispánica durante la Edad Moderna ${ }^{3}$. Como señala la Regla Primitiva y Constituciones de los Religiosos Descalços de la Orden de Nuestra Señora del Monte Carmelo de la Congregacion de España...del año 1604, los arquitectos carmelitas debían formalizar las trazas de todos sus conventos ${ }^{4}$.

La biografía de este artista nos resulta hoy relativamente bien conocida ${ }^{5}$ aunque

${ }^{2}$ C. DE LA PeÑa Velasco, «Religiosos y matemáticos en las primeras décadas del siglo XVIII en Murcia», en Imafronte № 12-13, Murcia, 1998, p. 248.

${ }^{3}$ J. M. MUÑOZ JIMÉNEZ, La arquitectura carmelitana (1562-1580): arquitectura de los Carmelitas Descalzos en España, México y Portugal durante los siglos XVI al XVIII; Comisión Provincial del IV Centenario de la muerte de San Juan de la Cruz, Ávila, 1990 y «Diccionario de artífices del Carmelo Descalzo. Arquitectos y maestros de obra», en Revista Monte Carmelo, Vol. 100, Burgos, 1992, pp. 49-78.

${ }^{4}$ Regla Primitiva, y Constituciones de los Religiosos Descalços de la Orden de Nuestra Señora del Monte Carmelo de la Congregación de España hechas por autoridad apostólica de Nuestro Santísimo Padre Clemente Papa VIII. En el capitulo general que se celebro en el convento de San Pedro de Pastrana, Año de M.D.C.IIII. Año 1623, en Uclés, por Domingo de la Iglesia.

${ }^{5}$ P. L. ECHEVERRIA GOÑI y R. FERNÁNDEZ GRACIA, «Aportación de los Carmelitas Descalzos a la Historia del Arte Navarro. Tracistas y arquitectos de la Orden», 
aún tenemos notables lagunas 6 . En el siglo se llamaba José de Ágreda Ruiz de Alda y nació en Logroño probablemente en $1716^{7}$. Fue hijo de Domingo de Ágreda y de Catalina Ruiz de Alda y "tomó el santo habito de Hermano Donado"8 en el convento de Core$1 a^{9}$ (Navarra) el 4 de abril de 1734 a la edad de 18 años con el nombre de Fray José de San Juan de la Cruz ${ }^{10}$. En dicho convento navarro realizaría la profesión simple el 4 de mayo de 1736, teniendo lugar la profesión solemne en la fundación de Villafranca $^{11}$ (Navarra) el día 4 de julio de $1740^{12}$. La

en Santa Teresa en Navarra en el IV centenario de su muerte (ed. José María Jáuregui); Pamplona, 1982, pp. 195-199.

${ }^{6}$ A pesar de los estudios llevados a cabo sobre la producción artística de Fray José de San Juan de la Cruz, el acercamiento a su trayectoria profesional presenta aún sensibles lagunas. Por lo que respecta a las carencias en su biografía hay que reseñar la pérdida de la documentación del Convento Carmelita de Logroño, donde falleció, residió gran parte de su vida y tuvo taller, tras el derribo consumado de la fábrica en 1810 en plena Guerra de la Independencia (S. DE SANTA TERESA, Historia del Carmen Descalzo en España y Portugal. Tomo XXII; Imprenta y Editorial Monte Carmelo, Burgos, 1944, pp. 846-847). A ello se une también la escasez de testimonios conservados sobre su estancia y actuación en otras casas profesas en las que residió, o permaneció alojado temporalmente como Villafranca, Burgos y Burgo de Osma.

${ }^{7}$ Los datos referidos en este documento no concuerdan con aquellos reflejados en su óbito, que señalan el año 1714 como el de su nacimiento. Estimamos que, sin embargo, estos últimos son erróneos, pues tampoco hay coincidencia con el año de profesión, que según el documento de fallecimiento tuvo lugar en 1733.

8 APNV. APN.4-Hab. Prov. Navarra 1732-1834. APCCor. 4 de abril de 1734 .

${ }^{9}$ El convento del Carmen en Corella se fundó en 18 de julio de 1595. Durante los siglos XVII y XVIII funcionó en diversas etapas como sede del primer año de profesos y noviciado.

${ }^{10}$ El culto a San Juan de la Cruz se reactivó a partir de 1726, fecha en la que fue canonizado.

${ }^{11}$ La fundación canónica se realizó el 14 de febrero de 1734 . Las obras del convento e iglesia se extendieron hasta el 24 de diciembre de 1765. vida de Fray José de San Juan de la Cruz transcurriría en el seno de la orden carmelitana a la que sirvió siempre con celo. Su fallecimiento acaeció el día 16 de septiembre de 1794 en el convento de Logroño, según lo indica el Becerro de Difuntos de dicho cenobio, a los 80 años y 61 de vida religiosa. En sus hojas se ilustra la personalidad de este hermano lego mostrándole no sólo como un consumado artista sino también como un carmelita sumamente devoto ${ }^{13}$.

El gran talento y habilidad en el oficio de Tracista y Escultor, manifiesto en el obitua-

12 APNV. A-III-1. Becerro de Villafranca prof. Agradecemos la información al Padre Antonio Unzueta, Archivero Provincial de la Provincia de San Joaquín de Navarra con sede en Vitoria.

${ }^{13}$ Becerro de Logroño dif. № 151: En 16 de septiembre de 94 fallecio en este Colegio el Hermano Fr. Josef de $S^{n}$ Juan de la Cruz (natural de Logroño) de un vaido de cabeza de que le resultaron unas calenturas que ael quarto dia le quitaron la vida. Fue la de Nro Hermano de verdadero Carmelita Descalzo. De todos era sumamente amado no solo por su gran talento y habilidad en el oficio de Tracista y Escultor, sino mucho mas por su trato afable y humano para con todos. Era mui aplicado ael trabajo, y nunca se le encontraba ocioso aun en los ultimos dias de su vida quando apenas podia valerse de sus miembros. Asistia puntualmente ael coro en aquellos tiempos que los exercicios de su oficio le permitian y especialmente a la oracion que casi nunca dexaba de asistir aella y perseberar de rodillas con ser que estaba casi imobil y lleno de varios achaques de su abanzada edad si la obediencia le dispensaba de algunos actos de mortificacion, los suplia en su taller donde varios Religiosos le oian muchas vezes tomar disciplina con mucho fervor $y$ espiritu. Se abstenia de las cosas de alibio que con licencia de sus Prelados podia usar licitamente. Observaba con mucha puntualidad el santo silencio con particularidad en los tiempos y lugares prohibidos y jamas se le vio hablar una palabra sino es que fuese mui necesaria para algun negocio. Era mui amigo de que las cosas que sirven ael culto divino estuviesen mui aseadas y limpias. Sentia en el corazon cualquiera irreverencia que se hacia en las Iglesias. Y el mismo reprendia muchas vezes a los que no hacian como se debe las genuflexiones delante de el SSmo Sacramento. Gustaba mucho de hablar cosas espirituales, y buscaba modos para hacer conversación delas cosas que leia en los libros debotos. Tenia de edad 80 años y de Religión 61. Esta enterrado en la capilla de N. Me SSma de el Carmen (fabricada por el mismo) en la sepultura numero 17. Requiescat ynpace. 
rio, se evidencia en sus muchas obras que se mueven en la dicotomía de un apego a la sobria arquitectura carmelitana en sus trabajos conventuales y la profusa decoración que presentan sus realizaciones para otros comitentes. Así lo expresan, por un lado, la obra del Convento de las Madres Carmelitas de Lesaca ${ }^{14}$ (1767) de gran fidelidad a la sencillez estética del Carmelo, en contraste con sus trabajos en San Gregorio Ostiense de Sorlada $(1757-1765)^{15}$, la sacristía de la Catedral de Burgos (1760-1767) ${ }^{16}$ y la capilla de las Reliquias de ese templo (1762-1765) 17 , que se definen por su carácter sumamente ornamental. Su enorme prestigio le llevó a actuar como experto, tasador o informante en muchas obras de arquitectura que se estaban realizando en un amplio territorio entre Burgos, Navarra y La Rioja ${ }^{18}$. Prueba

-

${ }^{14} \mathrm{M}^{\mathrm{a}}$ C. GARCíA GAINZA, «El Convento de Carmelitas Descalzas de Lesaca», en Boletín del Seminario de Arte y Arqueología, XXXIX; Valladolid, 1973, pp. 333334.

15 VV. AA., Catálogo Monumental de Navarra II/II. Merindad de Estella; Fundación Príncipe de Viana/ Universidad de Navarra, 1983, pp. 504-514 y J.J. AZANZA LÓPEZ, Arquitectura religiosa del barroco en Navarra; Departamento de Educación y Cultura del Gobierno de Navarra, 1998, pp 404-414.

16 J. MATESANZ DEL BARRIO, Actividad artística en la Catedral de Burgos de 1600 a 1765; Caja de Burgos, Burgos, 2001, pp. 405-468 y Catedral de Burgos. Sacristía Mayor. Historia, arte y restauración; Cabildo Metropolitano/Fundación Winthertur, León, 2010.

17 J. MATESANZ DEL BARRIO, Las capillas de San Juan de Sahagún y de las Reliquias en la Catedral de Burgos; Caja Círculo (Obra Social), Burgos, 2008, pp. 54-62.

${ }^{18}$ En 1756 firmó un dictamen para la restauración de la iglesia parroquial de Viana (VV. AA., Catálogo Monumental de Navarra II/II. Merindad de Estella; Fundación Príncipe de Viana/ Universidad de Navarra, 1983, pp. 504-514). Durante los años 1757 y 1759 llevó a cabo el diseño y reconocimiento de seis retablos colaterales obra de Manuel Solano, Manuel de Moraza y Sebastián de Portu en Labastida (VV. AA.: Catálogo Monumental Diócesis de Vitoria I. Rioja alavesa; Caja de Ahorros Municipal de Vitoria, 1967, p. 215). En 1760 examinó la torre de la Catedral de Santo Domingo de la Calzada severamente dañada (J.M ${ }^{a}$ FERNÁNDEZ SAN MILLÁN, de su fama la tenemos en el hecho de que la comunidad benedictina de Santo Domingo de Silos trató de contratar sus servicios en 1769 para que inspeccionase la obra de la nueva iglesia que estaba ejecutando sobre los planes de Ventura Rodríguez, lo que evidencia que la comunidad silense debía tener algunas dudas sobre la orientación estética sobre la que se estaba desarrollando ese proyecto ${ }^{19}$.

Por lo que respecta a la obra escultórica y retablística desarrollada en Álava ${ }^{20}$, Navarra ${ }^{21}$ y La Rioja ${ }^{22}$ nos enfrentamos a un artista apegado a las formas barrocas en sus imágenes religiosas. En el ornato de sus retablos Fray José de San Juan de la Cruz se movió entre un primer período de acomodo a la denominada "talla valenciana", para posteriormente adoptar en su producción un lenguaje rococó con "decoraciones chinescas".

El hermano lego carmelita ejercitaría igualmente otras disciplinas científicas y

Santo Domingo de la Calzada. Guía de la Catedral; Cabildo de la S.I. Catedral de Santo Domingo de la Calzada, Logroño, 1992, p. 20) y también realizó la tasación de una caja de órgano en la parroquia de la Asunción de los Arcos, compuesta por el escultor Diego Camporredondo y el dorador Santiago Zuazo (Sobre Diego Camporredondo ver el libro de J. A. SEgURA JiMÉnEZ, Diego Camporredondo y el arte barroco y rococó en Calahorra y su comarca; Gobierno de La Rioja/Instituto de Estudios Riojanos, Logroño, 1994).

${ }^{19}$ C. J. Palacios Palomar: Patrimonio artístico y actividad arquitectónica del Monasterio de Santo Domingo de Silos (1512-1835), Stvdia Silensia. Series Mayor IV; Abadía de Silos, 2001, pp. 224-225.

${ }^{20}$ VV. AA., Catálogo Monumental Diócesis de Vitoria I. Rioja alavesa; Caja de Ahorros Municipal de Vitoria, 1967, pp. 41 y 215.

${ }^{21}$ J. J. AZANZA LÓPEZ, Arquitectura religiosa del barroco en Navarra; Departamento de Educación y Cultura del Gobierno de Navarra, 1998, pp 404-414.

22 J. M. RAMíreZ MARTíneZ, Retablos mayores de La Rioja; Obispado de Calahorra y La Calzada, Agoncillo, 1993 y J.M. RAMÍREZ MARTÍNEZ, La evolución del Retablo en La Rioja. Retablos Mayores; Logroño, 2010. 
artísticas. En el campo de la ingeniería ${ }^{23}$, construyó un ingenio hidráulico para la extracción de agua en la localidad de Alfaro. Actuó como dorador en la obra de la sacristía de Burgos ${ }^{24}$ y también dictó condiciones para el dorado de un retablo colateral en la parroquia de San Asensio en La Rioja ${ }^{25}$. Por último, practicó el arte del grabado, según tendremos oportunidad de estudiar, campo de actuación artística al que hasta ahora nadie se había referido.

Fue la tendencia a los excesos ornamentales de este arquitecto la que hizo que, desde la década de 1760, se fueran produciendo críticas a este profesional por los seguidores del Barroco Clasicista y del primer Neoclasicismo y la causa que explicaría, además de los desencuentros con importantes profesionales cortesanos, el ocaso de sus propuestas, tras lustros de éxitos artísticos, en los últimos años de vida. Ocaso que fue evidente, en 1782, al quedar rechazado, por el Conde de Miranda, su plan para el retablo mayor de la Colegiata de Peñaranda de Duero a favor del de Ventura Rodríguez ${ }^{26}$. La crítica al abigarramiento

${ }^{23}$ José Javier Azanza señala que en un documento de 1767 relativo a la construcción del convento de Carmelitas de Lesaca Fray José de San Juan de la Cruz se presenta como "Yngeniero Arquitecto" (J. J. AZANZA LÓPEZ, «Tipología de las torres campanario barrocas en Navarra», Revista Príncipe de Viana Año 59, № 214, Pamplona, 1998, pp. 333-392).

24 J. MAtesanz Del BARRIO, Actividad artística en la Catedral de Burgos de 1600 a 1765; Caja de Burgos, Burgos, 2001, pp. 405-468 y Catedral de Burgos. Sacristía Mayor. Historia, arte y restauración; Cabildo Metropolitano/Fundación Winthertur, León, 2010.

${ }^{25}$ AHPLR Leg. 4142/1, fols. 71 r-72 vo. P.N. Bernardo J. Puebla. Condiciones con las quales se ha dorar el retablo Colateral del Santtissimo Christo de la Iglesia Parrochial de la villa de San Asensio. Burgos, 27 de julio de 1761. Citado por J.M. Ramírez MarTíneZ en J. M. RAMíREZ MARTínEZ, Retablos mayores de La Rioja; Obispado de Calahorra y La Calzada, Agoncillo, 1993, p. 106.

${ }^{26}$ A. C. IBÁÑEZ PÉREZ «La introducción del Neoclasicismo en Burgos. Retablos y escultura», en Acade- decorativo que presentan algunos trabajos del fraile carmelita, está presente en un conocido texto de Antonio Ponz sobre la sacristía de la Catedral de Burgos que puso a esta realización arquitectónica y a su autor en el punto de mira de los críticos dieciochescos y decimonónicos ${ }^{27}$. Asimismo, como analizaremos con detalle en este artículo, la crítica también se refleja en el juicio desfavorable formulado sobre la apariencia de las obras de Fray José de San Juan de la Cruz por el pintor cántabro José Bejes o Berjes (1729-1785) ${ }^{28}$ y el arquitecto y retablista Sebastián de Portu ${ }^{29}$ en una instancia y Memorial remitidos a la Academia de Bellas Artes de San Fernando. La sacristía de la Catedral de Burgos y la cabecera de la basílica de San Gregorio Ostiense son para dichos artífices expresión de su estilo degradado ${ }^{30}$.

mia № 69, Madrid, segundo semestre de 1989, pp. 6869.

${ }^{27}$ Dando vuelta al semicírculo de la capilla mayor se halla la sacristía que, con la antesacristía, he oído costó de adornar cuarenta mil ducados: tal es la confusión de estucos, figuras, ornatos chinescos, paisajes y otras raras invenciones del arquitecto, que fue un religioso Carmelita (A. PONZ, Viaje de España (Tomo duodécimo); Viuda de Ibarra, Hijos y Compañía, Madrid, 1788. Reed. Editorial Aguilar (Vol.3), Madrid, 1988, p. 562).

${ }^{28}$ En relación con la obra de José Bejes, ver el libro de I. GUTIÉRREZ PASTOR, Catálogo de pintura del monasterio de San Millán de la Cogolla, Institutos de Estudios Riojanos, Logroño, 1984, pp. 55-69 y el artículo de F. TRUEBA PÉREZ, «Documentos y noticias sobre José de Bejes (1729-1785)», Altamira: Revista del Centro de Estudios Montañeses, Tomo LXIX, Santander, 2006, pp. 221250 .

${ }^{29}$ Por las fechas en que se fecha el documento podemos subrayar que se trata de Sebastián de Portu "el joven", maestro arquitecto y retablista riojano perteneciente a una familia de artífices procedente del País Vasco en la que destacó su padre, también llamado Sebastián de Portu.

${ }^{30}$ Dígalo la Sta. Ygl.a de Burgos en la Sacristia y otra en S." Gregorio que por ser obras que ha visto don Roberto Michel no queremos molestar a $V$.S. en referir las ridiculeces que ha echo y el mucho dinero que a mal empleado... (ARASF 2-24-7). 
2. FRAY JOSÉ DE SAN JUAN DE LA CRUZ Y JOSÉ BEJES. SUS RELACIONES ARTÍSTICAS A LA LUZ DE UNA INSTANCIA Y MEMORIAL PRESENTADOS A LA REAL ACADEMIA DE BELLAS ARTES DE SAN FERNANDO

Con fecha de 8 de mayo de 1769 el pintor Jose Bejes remitió a la Real Academia de Bellas Artes de San Fernando un Memorial en el que se alertaba a los miembros de dicha institución sobre las irregulares actuaciones artísticas del carmelita Fray José de San Juan de la Cruz en La Rioja y en otras regiones colindantes, solicitando que se le impidiese desarrollar su actividad profesional $^{31}$. Dicho documento va acompañado de una instancia que firma también el arquitecto y retablista Sebastián de Portu. El motivo último que explica la remisión de este Memorial al máximo organismo en cuestiones artísticas de España, de reciente creación $^{32}$, fue, como refiere Bejes, la ejecución por parte de Fray José de San Juan de la Cruz de la chapa y prueba de un grabado de Nuestra Señora de la Soledad para el convento de Nuestra Señora de las Mercedes de Logroño, negocio que él había tratado previamente con el comendador de dicha fundación. Bejes se ofreció a confeccionar un dibujo preparatorio para su posterior traslado a lámina metálica e impresión por un maestro especialista en Madrid. Informado del proyecto, Fray José entró en contacto con la comunidad de Nuestra Señora de las Mercedes haciéndose cargo de la realización de la estampa por un valor de 600 reales. Dicho coste, en palabras del fraile José, sólo "llevaba la mitad de su justo precio", cuantía que sin embargo Bejes estimaba abusiva para el resultado obtenido, como en su opinión ponía de manifiesto el

\footnotetext{
-

${ }^{31}$ ARASF 2-24-7.

${ }^{32}$ C. BÉDAT, La Real Academia de Bellas Artes de San Fernando (1744-1808); Fundación Universitaria Española, Madrid, 1988.
}

ejemplar de la misma que incorporó al Memorial para examen de los académicos. La relación de este episodio evidencia una notable divergencia artística entre el pintor y el lego carmelita, cuyos caminos profesionales se habían cruzado en numerosas ocasiones, estando documentada la presencia de ambos en proyectos comunes.

José Bejes había nacido en 1729 en la localidad cántabra de Potes $^{33}$, población de la que eran naturales sus padres José Bejes (o Berjes) y Petronila Delgado. Tras un período intenso de aprendizaje con cortas estancias en Madrid, Roma, Nápoles, Centroeuropa y Londres, se establecería en Logroño en 1755 donde contrajo primeras nupcias con Manuela García de Arciniega, hija del pintor Juan José García de Arcinie$\mathrm{ga}^{34}$, quien le introduciría en el foco artístico riojano colaborando con él en varios trabajos. La vida de Bejes se desarrollaría a partir de entonces en estas tierras, donde nacerían sus hijos, contraería nuevas nupcias con Antonia Ocio y fallecería el 1 de febrero de 1785, como señala su acta de defunción ${ }^{35}$. Su obra, abundante en La Rioja, Navarra y País Vasco, estuvo marcada por una evolución del estilo en el que se denotan sucesivamente las influencias de Ribera, Luca Giordano, así como el eco de la estética rococó a través de la obra de Corrado Giaquinto que conocería en sus desplazamientos a Madrid ${ }^{36}$. Ha sido defi-

\footnotetext{
${ }^{33}$ F. B. TORRALBA SERRANO, «Jose Bexes y los decoradores barrocos logroñeses», Berceo № 34, 1955, p. 57.

${ }^{34}$ En 1756 aparece firmando junto con Arciniega el contrato del dorado de retablos y pintura de las capillas de San Jerónimo y de los Reyes de la iglesia de Nuestra Señora de Palacio en Logroño.

35 F. TRUEBA PÉREZ, «Documentos y noticias sobre José de Bejes (1729-1785)», Altamira: Revista del Centro de Estudios Montañeses, Tomo LXIX, Santander, 2006, p. 247.

36 I. GUTIÉRREZ PASTOR, Catálogo de pintura del monasterio de San Millán de la Cogolla, Institutos de Estu-
} 
nido como un pintor convencional y superficial, con criterios eclécticos y conocedor de amplias fuentes grabadas ${ }^{37}$. A pesar de la cierta modestia que define su obra siempre tuvo una alta consideración sobre su persona llegando a solicitar que en virtud del ejercicio de su arte se le librara de pagar impuestos en su localidad de Logroño ${ }^{38}$.

El conocimiento de Bejes de la obra de Fray José de San Juan de la Cruz en el ámbito de La Rioja y Álava fue de primera mano, pues ambos artistas figuran participando en diversos encargos para los mismos comitentes. Así lo certifica la participación de Fray José de San Juan de la Cruz y José Bejes en la obra de unos retablos en la parroquia de La Asunción de Labastida a fines de la década de 1750. El lego carmelita

dios Riojanos, Logroño, 1984, pp. 55-56.

37 A. E. PÉREZ SÁNCHEZ, Pintura Barroca en España (1600-1750), Cátedra, Madrid, 1992, pp. 428-429; I. GUTIÉRREZ PASTOR, «La pintura del siglo XVIII en La Rioja», Historia del Arte en La Rioja. Los siglos XVII Y XVIII, Logroño, 2009, pp. 387-400.

${ }^{38}$ Logroño, 8 de agosto de 1770. Petición de cumplimiento de decreto de exención de impuestos y otras cargas a José Bejes, maestro pintor, vecino de Logroño por el Síndico de dicha ciudad. Jospeh Bejes Maestro Pintor vezino de estta ciudad de Logroño. Digo que en diez y siette de Marzo del año pasado de mil setecientos y cincuenta y siette ocurri a la Real Chancillería de Valladolid haciendo relación de ser ttal Maestro y de que la cofradía del Santísimo Sacramentto y San Lucas evangelistta sittas en el Colegio de Niñas Huerfanas extramuros de dha ciudad de Valladolid, havia obtenido diferentes carttas ejecuttorias en razon de que a los Pinttores, Doradores, Arquitectos, ensambladores y escultores de la expresada Ciudad, y demas de los reinos de S. M. (que dios gûu), no se les repartiese por ningunas Justicias en donde residieren ni por otras Personas, Alcabalas, Cienttos, soldados, Huéspedes, Carruajes, ni ottras cargas concejiles por ser dichos Arttes Nobles y liverales, cuias esempziones y regalias se les ha mandado guardar por repetidos auttos de los señores de dhc Real Chancillería, como lo hize consttar por Papeles, testimonios, y ottros Documentos que entonces presentte; y en consecuencia y con su vistta, se mando despachar su Real Provision, para que la Justicia de esta ciudad donde estoy avecindado, me hiziesen guardar lo concedido por Reales Provisiones y carttas ejecuttorias a mi favor despachadas... (ARChVa. Pleitos Civiles Lapuerta (F) №4 3585-10). es citado como autor de la traza y reconocimiento de unos retablos colaterales del templo en 1757 y 1759, recibiendo como pago un total de 577 reales en dos partidas ${ }^{39}$, mientras que Bejes se encargó de realizar el reconocimiento de la escultura de estos retablos, labor por la que se le abonaron 45 reales en 1760 y 3.900 por estofar$\operatorname{los}^{40}$. Asimismo a través de diversa documentación parroquial y de protocolos notariales atestiguamos la presencia de Bejes y Fray José de San Juan de la Cruz en Logroño, Viana y Calahorra, trabajando en diferentes empresas a lo largo de los mismos años, hecho que les permitiría tener un conocimiento mutuo de sus actuaciones.

José de San Juan de la Cruz dejaría su huella en el desaparecido convento de carmelitas de la ciudad de Logroño en el que realizó la capilla de la Virgen del Carmen. En la localidad navarra de Viana está documentado en las iglesias de San Pedro y Santa María los años 1748, 1754 y 1756 y en Calahorra se le atribuye la presentación de una traza en 1755 para la obra del retablo de la capilla de los Reyes de la catedral ${ }^{41}$. Por su parte, José Bejes realizó en 1756 la decoración pictórica de la capilla mayor de la iglesia de San Pedro de Viana42, así como

${ }^{39}$ VV. AA., Catálogo Monumental Diócesis de Vitoria I. Rioja Alavesa; Caja de Ahorros Municipal de Vitoria, 1967, p. 215.

${ }^{40}$ VV. AA., Catálogo Monumental Diócesis de Vitoria I. Rioja Alavesa; Caja de Ahorros Municipal de Vitoria, 1967, p. 216. José Bejes se haría cargo de otros trabajos en esta parroquia como la realización del nuevo monumento de Semana Santa en 1756 y la pintura de la cúpula del templo junto con José López Bajo.

${ }^{41}$ P. L. ECHEVERRIA GOÑI y R. FERNÁNDEZ GRACIA, «Aportación de los Carmelitas Descalzos a la Historia del Arte Navarro. Tracistas y arquitectos de la Orden», en Santa Teresa en Navarra en el IV centenario de su muerte (ed. José María Jáuregui); Pamplona, 1982, pp. 195-199.

${ }^{42}$ A. J. MAteos GiL, «Clasicismo y Barroco en la capilla de los Mártires de la Catedral de Calahorra», Berceo № 154, Instituto de Estudios Riojanos, Logroño, 
varios lienzos. Dejó importantes muestras de su arte en las capillas de la cabecera (1757) y claustro de la iglesia de Santa María de Palacio de Logroño y en la capilla de los Ángeles (1762-1763) de la actual Concatedral de Santa María la Redonda de Logroño. Asimismo, se conservan de él notables trabajos en la girola, capilla de los Mártires (1765) y sacristía de la Catedral de Calahorra ${ }^{43}$.

Fue, sin embargo, la crítica vertida por Bejes al proceso de construcción por Fray José de San Juan de la Cruz de un ingenio hidráulico para irrigar las huertas de un convento en Alfaro ${ }^{44}$ el suceso que marcó la ruptura entre ambos artistas, y raíz de la querella presentada por el pintor cántabro a la Real Academia de Bellas Artes de San Fernando contra el lego carmelita. Fray José se había comprometido a construir un "hinstrumento zelindrico" para sacar agua del río Ebro según indicaciones y diseño contenidos en el tomo cuarto del Compendio matemático... del padre oratoriano Tomás Vicente Tosca (1651-1723) dedicado a la estática, hidrostática, hidrotecnia e hidrometría ${ }^{45}$. El Compendio matemático... era una enciclopedia compuesta por nueve tomos que exponían el conocimiento existente en dicha época sobre las "ciencias de la cantidad", según manifiesta su título. La

2008, p. 340.

${ }^{43}$ I. GUTIÉRREZ PASTOR, «La pintura del siglo XVIII en La Rioja», Historia del Arte en La Rioja. Los siglos XVII Y XVIII, Logroño, 2009, pp. 387-400.

${ }^{44}$ El documento del Memorial no suministra la fecha en que tuvo lugar este hecho. Tal vez lo podamos situar en 1759, año en que, según ha estudiado José Manuel Ramírez Martínez, Fray José de San Juan de la Cruz realizó un diseño de retablo para la ermita de San Roque de Alfaro.

${ }^{45}$ T. V. TOSCA, Compendio Matemático en que se contienen todas las materias mas principales de las Ciencias que tratan de la Cantidad que compuso el doctor Thomas Vicente Tosca, Presbitero de la Congregación del Oratorio de S. Felipe Neri de Valencia. Tomo IV (2 $2^{\mathrm{a}}$ edición); Imprenta de Antonio Marín, Madrid, 1727. difusión de este trabajo fue muy notable en las universidades y otros centros del saber hispano, formando parte con frecuencia de las bibliotecas de científicos, ingenieros, arquitectos, etc ${ }^{46}$. El trabajo del fraile riojano se centró en reproducir la figura 27 de la obra de Tosca en su cuarto volumen. Tal como señala Tosca, se trata del llamado tornillo de Arquímedes o cóclea, máquina para la elevación de agua, harina o cereales, ya descrita por Vitrubio en Los diez libros de arquitectura, compuesta por una espiral inclinada que gira accionada por una manivela en la parte superior. La acción de esta máquina, introducida en su parte inferior en el agua, provocaba el ascenso del líquido. Bejes advirtió al fraile carmelita de la dificultad extrema de extraer agua con el ingenio que había construido, debido a su gran tamaño (tenía 22 pies de alto). Como subraya el pintor, una vez rellena la bomba hidráulica de agua, fue imposible moverla entre seis legos y "un macho de los mejores del convento". La crítica formulada por Bejes sobre la competencia de Fray José de San Juan de la Cruz para ejercer trabajos de ingeniería hidráulica dañaría definitivamente las relaciones personales y profesionales entre ambos como expresa el pintor en el Memorial, pues desde entonces señala el pintor que "me ha hecho todo el mal que ha podido" 47 .

La instancia que acompaña al Memorial de Bejes viene firmada también por otro artífice riojano que se une a las reprobaciones escritas por el pintor. Se trata de Sebastián de Portu, que firma en el documento como "maestro de arquitectura", y cuya relación profesional y personal con Fray José y Jose Bejes venía de antiguo. Avecindado en Logroño, Sebastián de Portu "el joven"

\footnotetext{
${ }^{46}$ Buena prueba de ello lo muestra la biblioteca de la Academia de Artillería de Segovia, que cuenta con los nueve tomos de la colección entre sus fondos.

${ }^{47}$ ARASF 2-24-7.
} 
pertenecía a una familia de escultores guipuzcoanos oriundos de Andoaín y activos en tierras riojanas durante los siglos XVII y XVIII ${ }^{48}$. Ya hemos indicado anteriormente que los tres artistas intervinieron en la realización de unos retablos colaterales en la parroquia de Labastida. Sebastián Portu se encargaría de realizar entre 1753 y 1757 los retablos de San Pedro, el Santo Rosario, San Sebastián y el Santo Cristo de los Remedios, conforme al estilo Rococó imperante. Por dicho trabajo recibiría la cantidad de 11.932 reales y medio. La relación profesional de Sebastián de Portu con Fray José de San Juan de la Cruz debió estrecharse en años sucesivos, siendo este fraile el introductor y protector de Portu en la realización de importantes trabajos en el norte de La Rioja, entre los que destaca la obra del retablo colateral del Santo Cristo para la capilla de San Andrés en la iglesia de San Asensio, conforme a trazas y condiciones dadas por el carmelita ${ }^{49}$. Si el documento de la Real Academia de Bellas Artes de San Fernando explicita con claridad la razón del enfrentamiento entre Bejes y Fray José de San Juan de la Cruz, no da razón de los argumentos que motivaron a Portu a firmar dicho Memorial, aunque hemos de suponer que en algún momento de sus contactos profesionales surgirían las disensiones.

${ }^{48}$ En 1705 está documentado Sebastián de Portu "el mayor", especializado en trabajos escultóricos de madera y piedra, realizando las portadas laterales de Santa María la Redonda de Logroño. Trabajó también en la capilla de las Ánimas en la iglesia de Santa María de Palacio y las torres de Santa Coloma y Pedroso. José Manuel Ramírez Martínez subraya su relación familiar con José Ramírez, su cuñado, y la relación con los talleres de escultura en Soria de Lorenzo Rodríguez Cervantes, Domingo Romero, Juan López, Francisco Martínez Villar, Francisco Tejada y Juan Gil de Sopeña.

49 J. M. RAMírez MARTíneZ, Retablos mayores de La Rioja; Obispado de Calahorra y La Calzada, Agoncillo, 1993 p. 106.
La declaración de Bejes en la que señala que Fray José de San Juan de la Cruz se formó "sin mas maestro. que los libros del P. Vizente Tosca, ni haver visto, oído, ni tenido otra obligación de saber ni en donde aprender" ${ }^{\prime \prime 50}$, contrasta con el conocimiento teórico que el hermano lego carmelita parece tener de algunos tratadistas de la arquitectura del Renacimiento, según lo refleja un informe que realizó sobre la actuación de José del Castillo en la obra de la cabecera de San Gregorio Ostiense $\mathrm{e}^{51}$ y una de las cláusulas de las condiciones para realizar un retablo en la localidad de San Asensio, fechadas en 28 de mayo de 1759, donde son citados Sebastián Serlio, Andrea Paladio y León Baptista Alberti52. Sean o no estas referencias muestra de un conocimiento profundo de la teoría arquitectónica o tan sólo un envoltorio erudito que refleja una elevada autoestima profesional frente a sus contemporáneos riojanos, hay que negar la afirmación de Bejes sobre la pobre formación arquitectónica de Fray José, estando

\section{ARASF 2-24-7.}

51 J. J. AZANAZA LÓPEZ, Arquitectura religiosa del barroco en Navarra; Departamento de Educación y Cultura del Gobierno de Navarra, 1998, p. 408.

52 Ytem que se han de tomar las medidas de los cuerpos totales de arquitectura, segun la dimension de cada uno y se repartiran con todo rigor a las precisas medidas del Arte, sin que exceda, ni falte en las alturas y vuelos cosa alguna, a la , as justificada dimension de sus proporciones, sin que en esto aia voluntariedad, como algunos menos inteligentes mas llenos de ignorancia, y presunpcion, que suficienzia lo estan executando, con notable vilipendio de una tan noble Arte, queriendo corregir, con sus desairadas y desproporcionadas ideas, las medidas y proporciones, que con tan general aplauso, y aceptación de las edades, han seguido y siguen los verdaderos Arquitectos, con ellas, y no con otras, erigen sus edificios, si los quieren acertados, como lo aprueban Sebastián Serlio, Andrea Paladio, Leon Baptista Alberto y otros (AHPLR Leg. 4142/1, fol. 70 r. P.N. Bernardo J. Puebla. Condiciones que se han de observar en la execucion del retablo colateral que se ha de erigir en la Yglesia de esta villa de San Asensio. San Asensio, 28 de mayo de 1759. Citado por J. M. RAMíreZ MARTíneZ, Retablos mayores de La Rioja; Obispado de Calahorra y La Calzada, Agoncillo, 1993, p. 123). 
probado el conocimiento de algunos tratados clásicos como el de Fray Lorenzo de San Nicolás Arte y uso de la arquitectura ${ }^{53}$.

En la formación arquitectónica de Fray José, cuyo inicio desconocemos ${ }^{54}$, pudo tener un importante papel el contacto con destacados arquitectos carmelitas de su orden, como Fray Marcos de Santa Teresa (1677-1744?), activo durante la primera mitad del siglo XVIII en tierras vascas y navarras, donde profesó como conventual en el convento de Santa Ana de Pamplona y, sobre todo, con Fray José de los Santos ${ }^{55}$ (1697-1769), "tracista y maestro de obras" que trabajó abundantemente para su orden, a la que sirvió en los conventos de Lerma, Pamplona, Corella, Villafranca y Calahorra. La cronología de la intervención de Fray José de los Santos en obras conventuales de la orden en Corella y Villafranca, localidades en las que residió como conventual Fray José de San Juan de la Cruz, permiten respaldar este trato directo ${ }^{56}$.

El Memorial escrito por Bejes explicita la valoración del pintor sobre las principales obras del lego carmelita, aportando algunos elementos de juicio de gran interés para analizar la situación del arte español en la segunda mitad del siglo XVIII que se debate entre una corriente castiza y otra

53 J. J. AZANAZA LÓPEZ, Arquitectura religiosa del barroco en Navarra; Departamento de Educación y Cultura del Gobierno de Navarra, 1998, p. 408.

${ }^{54}$ Desconocemos qué oficio pudo desempeñar antes de su ingreso como hermano lego carmelita, y si existe algún antecedente familiar en el oficio de la construcción.

55 J. M. MUÑOZ JIMÉNEZ, «Diccionario de artífices del Carmelo Descalzo. Arquitectos y maestros de obra», en Revista Monte Carmelo, Vol. 100, Burgos, 1992, pp. 68-69.

${ }^{56}$ José Javier Azanza subraya que Fray José de los Santos debió intervenir a partir de 1734 en la obra del Convento de Carmelitas Descalzos de Villafranca, fundación en la que hizo su profesión solemne en 1740 Fray José de San Juan de la Cruz. venida del exterior y también muestra la entrada de los aires clasicistas frente a los últimos destellos del Rococó.

\section{UNA NUEVA OBRA DE FRAY JOSÉ DE SAN JUAN DE LA CRUZ A LA LUZ DEL MEMORIAL DE LA ACADEMIA: LA SA- CRISTÍA DE LA IGLESIA PARROQUIAL DE SANTO TOMÁS EN HARO.}

En los folios del Memorial escrito por Bejes se suministran importantes informaciones sobre las obras realizadas por Fray José. Una de ellas alude a la construcción por el hermano lego carmelita de una sacristía en Haro. Esta obra corresponde, como veremos, a la sacristía nueva que se realizó durante el último tercio del siglo XVIII en la parroquia de Santo Tomás de Haro, con presupuesto inicial de 14.000 ducados $^{57}$.

La realización de una nueva sacristía para la parroquia de la villa de Haro fue un proyecto largamente ansiado por el clero de la misma y la feligresía, como refiere un documento notarial de 11 de febrero de 1711 suscrito ante el escribano Miguel de Frías, que recoge unos acuerdos firmados en la sala capitular del templo el día 22 de septiembre de 1708 . Los comisarios señalaban, en una de las cláusulas, que existían fondos suficientes para poder ejecutar diversas obras de exorno del templo entre las que se cita la realización de una nueva sacristía $^{58}$. Dicho proyecto global tenía por

\footnotetext{
${ }^{57}$ En la billa de Aro 8 leguas de esta ciudad estan sus Hermanos y demas Parentela con todos los baldados que no pueden por si aspirar sino a un jornal, por su poca abilidad, executando una sacristia que dho. padre trazo y dirije donde ba a menudo a desengrasar, ajustada en catorze mil ducados que si la cuenta sale como en otras obras es regular pase de 28 a mil... (ARASF 2-24-7).

${ }^{58} Y$ considerando dichos sres. otorgantes que con lo que llevan ofrecido a dicha Iglesia Parrochial de esta Villa y con lo que al presente done y fueren produciendo sus rentas se puede poner execuzion, en dar prinzipio a las referidas
} 
finalidad mejorar y renovar la imagen de uno de los templos más destacados de La Rioja $^{59}$.

Las obras previstas en el documento de 1711 se fueron llevando a cabo paulatinamente: disposición de enlosado de un pie de grueso para la división del presbiterio y de la nave central realizado por Martín de Mendiola con piedra de Atamauri, sustitución del deteriorado retablo mayor de Felipe de Vigarny por otro nuevo, realizado en 1730 por Santiago del Amo ${ }^{60}$ conforme a trazas dadas por Fray Pedro Martínez en 1711, construcción de dos retablos colaterales dedicados a Nuestra Señora del Amor Hermoso y de la Virgen del Rosario en 1718 y edificación de una nueva sacristía a partir de 1769.

Domingo Hergueta y Martín nos proporciona algunos datos de relevante interés por lo que respecta a la ejecución

hobras de encajonado, enlosado, sacristia y retablo de su Capilla mayor, de un acuerdo an resuelto se ocurra ante el señor Provisor de este ob(is)p(a)do para que siendo de su agrado preste su lizienzia y expreso consentim ${ }^{\text {to }}$ para hazer dhas hobras... (AHPLR Leg. 3.949, fols. $63 \mathrm{r}-65$ vํ․ P.N. Miguel de Frías. Scriptura de los señores Comisarios de la Iglesia en virtud de comision de sus comunidades. Haro, 11 de febrero de 1711).

${ }^{59}$ Sobre el antiguo espacio de una iglesia del siglo XIV, fue construido el nuevo templo entre 1534 y 1547 por Juan de Rasines, y continuado por Pedro de Rasines (1564), Rodrigo de Rasines (1573), Pedro de Origoitia (1589-1600), Andrés García de Origoitia (1601-1603) y Andrés de Benea y Pedro de Benea (1603). Junto a estos maestros debemos citar también por su importancia a Felipe Vigarny, autor de la portada principal fechada en 1516 bajo el mecenazgo de los Fernández de Velasco, y a Juan de Raón (1671) y Agustín Ruiz de Azcárraga (1719-1721) en la fabricación de distintos elementos de la torre parroquial (J. M. RODRÍGUEZ ARNÁEZ, Haro. Guía de arte; Madrid, 1995).

60 J.M. RAMÍREZ MARTíNEZ, Retablos mayores de La Rioja; Obispado de Calahorra y La Calzada, Agoncillo, 1993, p. 334. Domingo Hergueta señala que el retraso en la construcción del retablo mayor vino motivado por la realización previa de la obra de la torre por Agustín Ruiz de Azcárraga con un coste de 12.433 reales. material de la sacristía ${ }^{61}$. Aunque Hergueta no señala que esta obra fue diseñada intelectualmente por Fray José de San Juan de la Cruz sí que indica que fue ejecutada materialmente por Jacinto de Olara y José de Amendio, que también serían responsables de la construcción del antecamarín y la antesacristía. Los protocolos notariales de la ciudad de Haro permiten conocer algunos datos sobre los artífices encargados de la fabricación de la sacristía ${ }^{62}$. Jacinto de Olara fue vecino de la ciudad de Haro, tal como manifiesta en el documento matrimonial con Vicenta de Uriarte, su segunda espo$\mathrm{sa}^{63}$. Era hijo de Juan de Juan de Olara y de María Bolívar, residentes en el lugar de Arrazola, población vizcaína del Duranguesado. El documento de testamento de Jacinto de Olara aporta nueva información de gran interés para el desarrollo de su biografía personal y artística ${ }^{64}$

${ }^{61}$ D. Hergueta y MARTíN, Noticias históricas de la muy noble y muy leal ciudad de Haro; Haro, 1906. Reedición de la Unidad de Cultura de la Excma. Diputación de Logroño. Servicio de Publicaciones, Logroño, 1979, p. 433.

62 Sobre la documentación relativa a las manifestaciones artísticas en Haro correspondientes al siglo XVIII, reflejadas en la documentación de archivo, ver el artículo de Y. CASAS MARTíNEZ, «Las artes en Haro durante el siglo XVIII a partir de las fuentes documentales», Berceo № 112-113, Logroño, 1987, pp. 33-92.

${ }^{63}$ AHPLR Leg. 4.133, fols. $50 \mathrm{r}-50$ vo . P. N. José Ochoa Retana. Mattrimonial enttre Jazinto Dolara y Vizentta de Uriartte. Vezino de estta villa de Haro y la otra residente en ella y naral. De la ziudad de Vittoria. 9 de mayo de 1777.

${ }^{64}$ En sus folios se indica que Olara era natural de Arraso (debe tratarse de la anteriormente citad localidad de Arrazola), y había estado casado en primeras nupcias con María Bengoa. Tras enviudar contrajo matrimonio con Vicenta Echabarría. El documento testamentario recoge la voluntad de que Olara sea enterrado en la parroquia de Santo Tomás de Haro, así como el nombramiento de su sobrino Juan de Olara, vecino de Aspe, como heredero universal. Por dicho testamento conocemos valiosos aspectos relativos a su actividad profesional. En este documento manifiesta que ha intervenido en algunas obras junto al maestro 
El documento testamentario da fe de la intensa actividad de Jacinto de Olara como cantero en la villa de Haro y en otras próximas como Briñas, señalando el nombre de algunos clientes para los que trabajó, tales como los presbíteros de Santo Tomás, Vicente y Diego López de Ollauri, Bernardo de Santa María, Prudencio de Mendieta, Juan de Echarri, Juan de Valentín y Ramón de Legarda. Los protocolos notariales de Haro informan además sobre otras intervenciones de Olara en Haro y su comarca ya desde 1752, año en que conciertan las obras de la casa de Juan de Almarza en las cercanías de la Plaza Mayor de la citada localidad, y su participación en diversos reconocimientos de obras junto los maestros de cantería Manuel de Aguirre, Diego de Retes, Andrés de Retes, Pedro Zalbide y Martín Cortázar ${ }^{65}$.

Si numerosos son los datos que podemos recabar en los protocolos notariales sobre Jacinto de Olara, no sucede lo mismo con José Amendio del que no se encuentra ninguna referencia. Este hecho puede deberse a una transcripción errónea del apellido Amendio, y tal vez haya que identificar a este autor con José de Mendía, que fue alarife en Haro en el último tercio del siglo XVIII y está documentado en diversas obras de arquitectura civil ${ }^{66}$.

La sacristía de la iglesia de Santo Tomás de Haro se encuentra ubicada en el costado del evangelio del templo, junto a la

cantero Pedro Zalbide, y también señala su relación con Francisco de Gutiérrez y Val, herrero, que la había fabricado distintas herramientas para su oficio de cantería. (AHPLR Leg. 4.303, fols. $53 \mathrm{r}-56$ vo . P. N. Pedro Sáenz Terrazas. Testamento de Jazinto de Olara vezino de esta villa. 6 de abril de 1784).

${ }^{65}$ Y. CASAS MARTÍNEZ, «Las artes en Haro durante el siglo XVIII a partir de las fuentes documentales», Berceo № 112-113, Logroño, 1987, pp. 33-92.

${ }^{66}$ Y. CASAS MARTíNEZ, «Las artes en Haro durante el siglo XVIII a partir de las fuentes documentales», Berceo № 112-113, Logroño, 1987, pp. 47 y 49. cabecera. Se accede a ella a través de una antesacristía de planta irregular rectangular, que en su interior alberga una fuente de mármol negro, comunicada con el templo por medio de una puerta con arco de medio punto, flanqueado por columnas corintias adosadas y entablamento de gusto rococó. Sobre él se disponen dos jarrones en sus laterales y en el centro un frontón roto con tiara eclesiástica, ángeles y la imagen del Espíritu Santo. Desde la sacristía se accede por una puerta lateral a un espacio que sirve de antecamarín a la capilla de la Soledad o del Santo Sepulcro (1735), costeada por la familia Coscojales, dispuesta en la parte posterior del retablo mayor.

La planta de la sacristía diseñada por Fray José muestra una estructura cuatrilobulada que circunda un ámbito cuadrado cubierto por cúpula sobre pechinas. Esta configuración no se manifiesta hacia el exterior, pues aparece como un prisma poligonal que recuerda el cimborrio exterior que enmascara la cúpula de la sacristía de Burgos por él trazada, utilizando un juego propio de la arquitectura barroca que oculta desde fuera la disposición interior y que también llevó a cabo en el convento de Carmelitas Descalzas de Lesaca. El modelo de sacristía de planta centralizada con cúpula de media naranja, aún siendo menor que el de planta rectangular se repitió con cierta frecuencia en las iglesias parroquiales y también se observa en algunas catedrales hispanas. El formato de la planta de la sacristía de la iglesia de Santo Tomás de Haro utilizado por Fray José, tiene un largo recorrido que nos aproxima a algunas empresas arquitectónicas romanas, tanto dentro de villas y estructuras palaciales, como de capillas adosadas a las basílicas de la primitiva arquitectura cristiana, mausoleos $y$ sacristías ${ }^{67}$. La pervivencia de estas estruc-

\footnotetext{
${ }^{67}$ Buena prueba de este tipo de proyectos la hallamos en varias estancias de la villa Adrianea de
} 
turas se mantendrá en las construcciones bizantinas y se recuperará con éxito nuevamente en el arte del Renacimiento italiano ${ }^{68}$, como da fe de ello la grandiosa iglesia de Santa María de la Consolación de Todi, propagándose posteriormente en el arte Barroco italiano.

El alzado de la sacristía de Santo Tomás de Haro, muestra una organización de los muros que combina los tramos curvos con los machones achaflanados que soportan los empujes de la cúpula central. En ellos el hermano lego dispuso dos pilastras cajeadas de capitel corintio, entablamento clásico y cornisa de gran vuelo, que recuerdan el diseño proyectado por él, años antes, en la sacristía de la Catedral de Burgos $^{69}$. Sobre este espacio central, Fray José de San Juan de la Cruz proyectará una cúpula gallonada con linterna sobre pechinas. Sobre un entablamento clásico de perfil quebrado se dispone la cúpula dividida en gajos que confluyen en el hueco de la linterna por pilastras cajeadas, a modo de fajas, que rematan en cabezas de ángel.

Los cuatro ámbitos laterales de la sacristía presentan nichos cóncavos cubiertos por bóvedas semiesféricas abiertas con ventanales. La presencia de edificios de planta centralizada con cubiertas de cas-

Tívoli, tres recintos adosados a la iglesia de San Lorenzo de Milán y en España en una sala del Mausoleo de Centecelles (S. IV) en Tarragona que presenta una idéntica distribución interna a la sacristía de Haro. En el volumen III de los Libros de Arquitectura de Sebastiano Serlio, encontramos dibujos de arquitecturas centralizadas con cúpula y exedras, pertenecientes a termas romanas. Recordemos que Fray José citó y debió conocer el tratado de este arquitecto.

${ }^{68}$ En el análisis de algunos ejemplos turolenses Santiago Sebastián subraya que este tipo de planta se inspira en prototipos renacentistas italianos.

${ }^{69}$ J. MATESANZ DEL BARRIO, Catedral de Burgos. Sacristía Mayor. Historia, arte y restauración; Cabildo Metropolitano/Fundación Winthertur, León, 2010, pp. 1819. quete y cabeceras trilobuladas con casquetes, no es algo inusual en la arquitectura barroca española. José Javier Azanza López, habla de su empleo en la actuación de los hermanos Manuel y José del Olmo en la iglesia del convento de las Comendadoras de Madrid, edificada a partir de 1667, su utilización en la obra de Pedro de Ribera en la iglesia de San Antón y en las soluciones dadas por Manuel Serrano para las iglesias de Renedo (1736) y Rueda (1738). José María Carreras Alonso identifica varias ermitas construidas con este tipo de planta a lo largo del siglo XVIII en el territorio de Daroca $^{70}$. La solución dada por Fray José de San Juan de la Cruz en la sacristía de Haro tiene un precedente próximo en la cabecera del santuario de San Gregorio Ostiense de Sorlada, construida conforme a un diseño presentado en $1758^{71}$.

El tipo de cúpula que utiliza Fray José de San Juan de la Cruz en la sacristía de Haro presenta una característica dúplice: por lo que respecta a la parte central es internamente gallonada y con linterna, mientras que los casquetes presentan ventanales, creando un sistema de iluminación que ya propone el padre oratoriano Tomás Vicente Tosca en las páginas de su Tratado de Arquitectura civil, montea, cantería y relojes y se observa en algunos ejemplares de la arquitectura barroca hispana como la iglesia de la Asunción de Priego en la provincia de Córdoba.

La apertura de vanos en los casquetes semiesféricos sigue un procedimiento muy barroco que ya usó Francesco Borromini en Sant Ivo de la Sapienza y que en

\footnotetext{
-

70 J.M. CARRERAS ASENSIO, «Ermitas barrocas de planta de cruz griega, cúpula y brazos semicirculares en el área de Daroca», en revista Xiloca, № 32, 2004, pp. 39-56.

${ }^{71}$ Fue elegido por el maestro de obras de San Ignacio de Loyola Fernando Agoiz, recibiendo 480 reales por su confección.
} 
España también reproduciría el Padre jerónimo José Pontones en el camarín de la Virgen de la Vega de Alcazarén. Los ventanales de la sacristía de la parroquia de Santo Tomás de Haro presentan al exterior una sección rectangular. Interiormente los vanos están perfilados por molduras con orejeras y de marco mixtilíneo similares a las que presenta el palacio de la plaza de la Cruz de la misma localidad ${ }^{72}$.

La estructura arquitectónica diseñada por Fray José de San Juan de la Cruz se completa con una ornamentación de estuco que, en origen, debió de estar policromada. El lego carmelita hizo uso en la obra de Haro de un procedimiento decorativo habitual en su producción arquitectónica, como vemos en la sacristía de la Catedral de Burgos y en San Gregorio Ostiense de Sorlada, y muy abundante en las tierras de Navarra donde comenzó su vida religiosa ${ }^{73}$.

No se han encontrado datos que permitan verificar el autor material de las yeserías, tanto por lo que respecta a su trabajo escultórico como a la policromía original de las mismas ${ }^{74}$. Sus rasgos formales

\footnotetext{
72 José Manuel A. Rodríguez Arnáez subraya el patrocinio de la familia Ángel en esta obra.

${ }^{73}$ José Javier Azanza señala que muchos templos y conventos navarros se ornamentaron interiormente con yeserías de motivos vegetales y geométricos. Por su riqueza destacan entre todas ellas las yeserías de la capilla de Santa Ana en la Catedral de Tudela, talladas por Juan Peralta en 1723.

${ }^{74}$ En el santuario navarro de San Gregorio Ostiense el autor de los trabajos en estuco diseñados por Fray José de San Juan de la Cruz fue Juan José Murga (J. J. AZANZA LÓPEZ, Arquitectura religiosa del barroco en Navarra; Departamento de Educación y Cultura del Gobierno de Navarra, 1998, p. 408). Manuel Romero Ortiz parece autor probable de la decoración de las yeserías de la sacristía de la Catedral de Burgos en las que también intervino directamente el lego carmelita, según manifiesta la documentación del archivo capitular (J. MATESANZ DEL BARRIO, Catedral de Burgos. Sacristía Mayor. Historia, arte y restauración; Cabildo Metropolitano/Fundación Winthertur, León, 2010, p. 12.).
}

tienen un gran sentido naturalista. Los motivos ornamentales se encuentran insertos en su mayoría dentro de cartelas de rocalla semejantes a los repertorios decorativos de Juste Aurèle Mesissonier y Gabriel Huquier que pueblan la cúpula central y los casquetes semiesféricos.

La lectura iconográfica de los motivos insertos entre la rocalla es de gran interés, y en algún caso, según analizaremos con detalle posteriormente, presenta un contenido significativo de orden religioso. En las cuatro pechinas que dan paso a la cúpula central identificamos cuatro bustos, colocados en parejas. En la cabecera encontramos dispuestos sobre una repisa las imágenes de Adán y Eva ${ }^{75}$, cubiertos por hojas de parra y circundados por motivos vegetales (árboles y flores), aves (figura de un cisne sobre Eva) y rocalla. En el costado opuesto se sitúan otros dos bustos en las pechinas, también vinculados entre sí por su significación. El primero representa la figura de una mujer vestida con pieles y tocada con zurrón. Está situada en un entorno con tres palmeras. Este árbol es el símbolo de la resurrección del alma, y puede prefigurar la imagen del justo, el cristiano fructífero, como subraya el libro de los Salmos ${ }^{76}$. En el lado opuesto, una mujer abrasada por el fuego y rodeada por serpientes que se asocian con el pecado y el mal, es la representación del infierno. En los casquetes y campos de la cúpula Fray José diseñó motivos de rocalla. Algunos de ellos llevan en su interior motivos de paisajes rurales, aves, etc. similares a los que diseñó para la sacristía de la Catedral de Burgos,

Santiago Zuazu será el responsable de la policromía de los relieves de estuco de Sorlada.

${ }^{75}$ Fray José de San Juan de la Cruz ya incorporó las imágenes de Adán y Eva en las pechinas de la sacristía de la Catedral de Burgos.

${ }^{76}$ Florece el justo como la palmera crece como el cedro en el Líbano (Salmos, 92, 13, p. 802). 
obra con la que está relacionada estilísticamente la sacristía de Haro.

Si importante es la obra arquitectónica de la sacristía de Haro, no lo es menos el amueblamiento que cubre sus diversos costados, también diseñado por el carmelita según un gusto rococó que lo aproxima al denominado estilo Luis XV77. La observación detallada del mobiliario apunta la extrema semejanza del proyecto con la obra que Fray José de San Juan de la Cruz diseñó para la sacristía de la Catedral de Burgos ${ }^{78}$, una vez más, precedente cercano con el que hay que enlazar la obra realizada en Haro. Así lo certifican los arquibancos situados en los costados de ingreso con altos respaldos divididos en tres calles y un cuerpo superior con espejo y las tres cajonerías que presentan un mueble de perfil abombado para guardar los ornamentos textiles litúrgicos con patas en forma de garra animal.

Los respaldos de la cajonería de Haro reproducen casi miméticamente el trabajo de la Catedral de Burgos. Lo podemos apreciar al observar las columnas corintias de fuste estriado con elementos decorativos de rocalla, las escenas de paisaje que incorpora en la predela, muy del gusto de Fray José$^{79}$, la presencia de espejos en un segundo cuerpo y las ornamentaciones que pueblan los paños compuestas por motivos animales, vegetales y de rocalla. Este parentesco formal aparece reforzado por el acabado de la madera sin policromar al igual que en la sacristía burgalesa. En lo que respecta a la ejecución del mobiliario, no disponemos de información que permita aven-

77 L. FEDUCHI. Historia del mueble; Naturart, 1994.

78 J. MATESANZ DEL BARRIO, Catedral de Burgos. Sacristía Mayor. Historia, arte y restauración; Cabildo Metropolitano/Fundación Winthertur, León, 2010, pp. 3135.

79 Aparecen incorporados en el retablo de San Asensio y en la cajonería de la Catedral de Burgos. turar quién o quiénes fueron sus tallistas. Muy probablemente se encargarían de llevar a buen puerto el proyecto del lego carmelita artífices con taller en la localidad o en otras poblaciones de La Rioja ${ }^{80}$. Domingo Hergueta facilita algunos detalles sobre la historia de la cajonería como el incendio del costado izquierdo de la sacristía que provocó el deterioro de importantes motivos escultóricos ${ }^{81}$.

El análisis descriptivo de la cajonería subraya la perfecta simbiosis existente entre el mueble y la arquitectura, adaptándose enteramente al perfil curvo de su planta y alzado. La disposición del mobiliario sigue un mismo esquema en los tres costados. En primer lugar, un mueble de perfil curvo apoyado en patas con forma de garra de león, que muestra un frente con tres cajones adornados en su centro con motivos de rocalla con dos aldabones de bronce. Los respaldos cuentan con una predela formada por paneles labrados con paisajes, cuerpo central articulado con columnas corintias de fuste estriado sobre ménsula, y decorado con espejos dispuestos entre guirnaldas de flores, animales y fragmentos de rocalla. El remate se desarrolla a través de una cornisa

${ }^{80}$ En el artículo de P. SÁNCHEZ PORTILlO, «Nuestra Señora de la Vega en Haro (La Rioja). Decoración de la basílica en los siglos XVII y XVIII», Berceo № 140, 2001, pp. 105-150, se cita el nombre de algunos artífices dedicados a labores escultóricas en Haro en la fecha de realización de la sacristía como Francisco Gurrea, maestro arquitecto y escultor nacido en Tudela y avecindado en Haro que intervino en diferentes obras de ambos oficios en Nájera, Fresneda, Huércanos, Haro, etc. y Manuel de Ágreda Ilarduy, patriarca de una dinastía de escultores que en 1770 establecería su taller en Haro, cuya obra ha sido objeto de análisis por M. FERREIRA FERNÁNDEZ en su tesis doctoral Los Ágreda: la evolución de escultura del taller barroco a la Academia Neoclásica.

${ }^{81}$ D. Hergueta y MarTíN, Noticias históricas de la muy noble y muy leal ciudad de Haro; Haro, 1906. Reedición de la Unidad de Cultura de la Excma. Diputación de Logroño. Servicio de Publicaciones, Logroño, 1979, p. 433. 
de perfil mixtilíneo labrada con diversos motivos ornamentales del gusto rococó. El mobiliario incluye también alacenas cerradas por puertas de madera con casetones para guardar los objetos de culto y otras piezas pertenecientes al tesoro parroquial.

La cajonería del costado izquierdo presenta en la predela del respaldo del primer mueble cuatro relieves: uno de ellos incorpora elementos de rocalla y los otros tres motivos figurativos de diversa índole como un copón con pie de base poligonal, astil de sección en forma de columna torsa y copa y cubierta en forma de esfera $y$, a sus lados, dos jarrones con plantas y en el fondo un paño extendido. En el lateral derecho el motivo representado es una custodia de mano con ostensorio en forma de sol. En el centro de ambos relieves observamos un paisaje rural con una fortificación en el centro y una casa en el lateral. El castillo muestra dos torreones circulares en los extremos, uno de ellos rematado en cúpula y con un ingreso con puerta de arco de medio punto bajo matacán almenado y una torre interior del homenaje. La estructura de la fortaleza recuerda el perfil del próximo castillo de Cornago. El cuerpo central presenta un panel lateral con un molino de viento dentro del campo de la rocalla. Los tres paneles centrales contienen elementos de rocalla, que rodean en el centro un espejo, dispuesto de forma similar a la cajonería de la sacristía de la Catedral de Burgos. El remate dispuesto sobre la cornisa se corona con un ático y remate de frontón curvo partido de perfil curvo con jarrones y motivos de rocalla de gran valor ornamental. El respaldo derecho de la cajonería izquierda reproduce idéntica estructura que en el anteriormente descrito. Los motivos representados en los tableros de la predela son: custodia y dos hacheros entrelazados por cintas de tela, a modo de trofeo; relieve con un paisaje con dos motivos principales, castillo con cuatro torres circulares, una de ellas cubierta por cúpula como en el panel antecedente y un puente; conjunto de objetos relacionados con el culto (cruz procesional, báculo, atril y birrete) nuevamente organizados entre cintas de tela, al modo de algunas representaciones de trofeos realizadas por el flamenco Cornelis $\operatorname{Bos}^{82} \mathrm{y}$ motivo de rocalla. El cuerpo segundo y remate reproducen los mismos elementos que el respaldo del costado opuesto, destacando el uso continuado de la rocalla en los diferentes paneles, disponiéndose en el interior de la tabla lateral una imagen del sol.

La cajonería de la derecha posee una disposición análoga a la del costado izquierdo: dos muebles con frente de tres cajones y respaldo superior y en el centro una alacena cerrada por dos puertas talladas con motivos geométricos, sobre las que sitúa un espejo con marco dorado de roca1la. En la predela del respaldo del primer mueble el autor o autores de la cajonería dispusieron cuatro paneles tallados, tres con motivos figurados y un cuarto con relieves de rocalla. En el mueble más cercano a la puerta de ingreso reconocemos un paisaje con una ermita rodeada por una cerca y una composición a modo de trofeo sostenido por cintas con una mitra, incensario, custodia de mano y cruz metropolitana, todos ellos objetos litúrgicos. El tablero central lleva encastrado un espejo perfilado en su exterior por rocallas. En el panel exterior, dentro de una rocalla se delinea una torre fuerte. El respaldo del segundo mueble está decorado en su predela con un panel que lleva en su interior un copón, vinajera y dos velas encendidas, una vista de una población amurallada, y diversas piezas de rocalla. Sobre la predela se dispone un espejo con las mismas características que en los otros paneles, perfilado por una rica talla de rocallas. El panel situado en el

\footnotetext{
${ }^{82}$ Fray José de San Juan de la Cruz había desarrollado ya este tipo de composiciones en las mesas de altar de la sacristía de la Catedral de Burgos.
} 
extremo contiene una cartela con un paisaje rural. El remate de la cajonería reproduce las formas y motivos ya vistos en el mueble del costado izquierdo.

La cajonería del ábside orientado al este exhibe una mayor riqueza ornamental que las dos laterales, presentando en el centro del respaldo un nicho concebido a modo de un pequeño retablo. Tres muebles con frente de cajones abombados cubren el perímetro inferior de su muro curvo. Sobre ellos se dispone un respaldo plenamente ornamental articulado por columnas estriadas sobre ménsula saliente. El centro lo ocupa un nicho cerrado con arco trilobulado. Su interior cobija el paisaje de una ciudad enclavada en un paisaje rocoso. Se trata de una recreación de Jerusalén, con el sol y la luna en sus costados tras un crucifijo. El abigarramiento ornamental de este relieve y la disposición de los diferentes elementos que lo conforman, aproximan la obra de Haro a composiciones presentes en algunos retablos tardogóticos de Borgoña y Flandes. Algunos de los detalles presentan una inspiración y conexión con edificios reales, otros están extraídos de grabados ${ }^{83}$.

La descripción de los paisajes del banco de la cajonería principal nos conduce, una vez más, como fuente de inspiración a la sacristía de Burgos con quien comparte diferentes motivos ornamentales. La identidad de imágenes expresa la utilización en Burgos y Haro de las mismas fuentes iconográficas que hemos podido encontrar en repertorios grabados, tomados frecuentemente como base de sus diseños por Fray José Si existe claramente una proximidad estética y ornamental de las dos cajonerías,

-

${ }^{83}$ Así lo sugieren la puerta torreada, similar en su estructura al arco de Santa María de Burgos -que fray José conoció en sus estancias en Burgos-, mientras que otros elementos como el templo circular de doble piso nos remite a fuentes grabadas en tratados del Renacimiento. sin embargo, hay que señalar por otro lado una notable distancia técnica en el acabado de ambas obras. Los relieves de la Catedral de Burgos muestran un mayor refinamiento y acabado que los de Haro, resueltos con mayor tosquedad. Siguiendo un recorrido de izquierda a derecha descubrimos en el primer tablero un núcleo urbano cruzado por una corriente fluvial. En su caserío destacan una fortificación unida a una arquitectura religiosa con un frente central de dos cuerpos rematado en frontón al que se accede por una escalinata. El segundo paisaje exhibe una vista rural recorrida en su centro por un río, junto al que se disponen varios monumentos de interés: una columna toscana ante un convento con frente de dos pisos rematado en frontón y claustro lateral con un ciprés en su centro, un molino y una iglesia con cúpula en un tramo de la nave y claustro lateral ${ }^{84}$. El tercero de los paneles es del máximo interés pues reproduce varios elementos ya presentes en la decoración de la cajonería de la sacristía de la Catedral de Burgos. El primero es un palacio torreado con dos edificaciones comunicadas por medio de un puente. Se trata del diseño titulado Palacio con foso extraído de una lámina diseñada por Hans Vredeman de Vries (Leeuwarden, 1527?1604) perteneciente al libro de Perspectivas de calles, plazas y patios (1562) grabado por Johannes y Lucas Doetchum, que reconocemos en el tercer panel de la predela en la cajonería izquierda de la sacristía burgale$\mathrm{sa}^{85}$. El segundo motivo recrea una fachada

\footnotetext{
${ }^{84}$ Todos los elementos de este relieve están presentes en algunos paneles de la sacristía de Burgos, el molino junto al río, la iglesia con cúpula, el paisaje montuoso, así como pequeñas figuras humanas como el pescador, el cazador y los venados que pueden reproducir de manera libre algunas composiciones grabadas de Adriaen Collaert.

85 J. MATESANZ DEL BARRIO, Actividad artística en la Catedral de Burgos de 1600 a 1765, Caja de Burgos, Burgos, 2001, pp. 405-468.
} 
de un templo de estirpe clasicista con cuatro cuerpos rematados en frontón con aletones laterales y tres calles, y una iglesia conventual anexa a un huerto con fachada con frente de tres cuerpos y nave cubierta por cúpula con linterna. El último panel representa un núcleo urbano situado en la desembocadura de un río al mar. Un puente y varios edificios civiles y religiosos pueblan el tablero marcado por su sentido decorativo y anecdótico de algunos detalles iconográficos. Junto a los paneles escultóricos la predela de esta cajonería tiene en el centro una interesante pintura sobre cristal con la Sagrada Familia, de probable origen italiano.

La ornamentación de los tableros del respaldo de la cajonería principal es más prolija que la de los muebles de los costados. Así lo reflejan las orlas que rodean los espejos compuestas por motivos de rocalla, florales, animales, diversos personajes y paisajes. La identificación y lectura de algunos de ellos es compleja por los desperfectos que causó el incendio anteriormente mencionado en su talla. El tablero izquierdo tiene encastrado en su centro un espejo con marco fileteado dorado. Una densa decoración de gusto rococó festonea sus costados con elementos de talla en altorrelieve. Una cartela de rocalla con un paisaje rural en su interior decora su parte inferior. Los laterales presentan rocallas de jugosa escultura. La coronación del espejo está ricamente decorada con tres asuntos figurativos: la imagen de un basilisco a la izquierda, un águila a la derecha y en el centro el rey David tañendo el arpa. El segundo tablero, con idéntica disposición que el antecedente, muestra en su flanco inferior una cartela de rocalla con árboles y un edificio en ruinas. Los motivos laterales de rocalla aparecen deteriorados en su superficie como consecuencia del incendio. En el extremo superior izquierdo los artífices del mueble labraron la talla de un elefante, enjaezado con una torre, mientras que a la derecha con- templamos una ardilla. Ambos motivos iconográficos recuerdan directamente los detalles ornamentales de la yesería de la cúpula de la sacristía de la Catedral de Burgos donde los introduciría también este fraile. El tercer panel, sigue idéntico esquema que los dos anteriores. El espejo central es perfilado por complejos motivos de rocalla. La cartela inferior repite elementos iconográficos habituales en los paisajes de esta cajonería: una torre fortaleza, un puente de cuatro ojos y arquería central y un templo con fachada que remata en frontón. Su diseño remite a varios detalles de los relieves de la cajonería de la sacristía burgalesa. Entre las rocallas laterales se desvelan varias figuras de animales: un pelícano y serpiente a la izquierda, y un ave y un gran pez. Sobre el espejo se esculpió una nube de la que asoman dos cabezas de ángeles. El cuarto y último panel con espejo muestra en su flanco inferior una cartela de rocalla nuevamente decorada con un paisaje rural. Las rocallas laterales encierran imágenes de dos aves, una lechuza a la izquierda y abubilla a la derecha, motivos iconográficos presentes en los respaldos de la cajonería de la sacristía burgalesa ${ }^{86}$. La coronación va tallada con una máscara y sobre ella un simio que porta en sus manos una pieza de artillería. Este último detalle vuelve a recordar la talla de la sacristía de la Catedral de Burgos, en la que como señala Bejes en su Memorial incluyó la figura de un mono cazando ${ }^{87}$.

${ }^{86}$ J. MATESANZ DEL BARRIO, Actividad artística en la Catedral de Burgos de 1600 a 1765; Caja de Burgos, Burgos, 2001, pp. 405-468 y Catedral de Burgos. Sacristía Mayor. Historia, arte y restauración; Cabildo Metropolitano/Fundación Winthertur, León, 2010, p. 439.

87 ...como en Burgos en la sacristia de la Santa Yglessi(a) donde perdio el juzio hiriendo disparates tan bisibles que entre las muchas figuras y niños y todo jenero de animales que tiene echos de bajo reliebe en la media naranja y sus pichinas a puesto una mona cazando con escopeta... (ARASF 2-24-7). 
El remate de la cajonería principal presenta algunas variaciones respecto a las laterales, abundando en una mayor riqueza decorativa. Ésta se manifiesta en el ático decorado con paisajes y rocallas y la disposición de tres relieves con efigies, en los laterales y en el centro. Las dos imágenes de los costados representan a dos presbíteros vestidos con dalmática que portan un incensario y dos vinajeras respectivamente. En el centro, la Verónica rodeada de nubes muestra el paño con el rostro coronado de Cristo. Cierra este grupo en su parte superior un relieve con la representación del sol entre nubes.

El valor de la sacristía de la iglesia de Santo Tomás de Haro transciende los aspectos estético, formal y técnico. Al igual que otras sacristías barrocas hispanas, los elementos decorativos que revisten la arquitectura y mobiliario presentan un rico programa iconográfico y simbólico de índole teológico. Creemos que el responsable de dicho programa, debió ser Fray José de San Juan de la Cruz que, como comprobaremos, tomó motivos y significados de la obra que ejecutó años antes en la Catedral de Burgos.

Un primer nivel de lectura nos habla de la función litúrgica del recinto a través de varios paneles de las cajonerías laterales. Copones, ostensorios, cruces metropolitanas, palmatorias, mitra, birrete, báculo, velas, etc., nos hablan de la significación que tiene el recinto en la iglesia en relación con la celebración del culto. Un segundo nivel de lectura, más complejo, hace referencia a los motivos escultóricos de la cajonería central que se ponen en relación con la decoración de yeserías de la cúpula. Fray José se valdrá para ello, al igual que ya lo hizo en la sacristía de la Catedral de Burgos, de un recurso iconológico muy antiguo, el teriomorfismo, que tuvo una amplia difusión en el arte paleocristiano y medie- val $^{88}$. Siguiendo este recurso, el lego carmelita identificará conductas y valores del ser humano con imágenes de animales, que portan un significado religioso. Fray José organizará este programa a través de la asimilación de emblemas contrapuestos. En el respaldo izquierdo de la cajonería central contemplamos un basilisco, animal fabuloso, compuesto de gallo y de serpiente, considerado emblema del odio, crueldad y la muerte $^{89}$. En el centro, la figura del rey David tañendo el arpa, nos acerca el significado que se concede a este instrumento musical, considerado como puente entre la tierra y el cielo. Por último, el águila -ave solar portadora del fuego y de la luz del cielo cuyo significado se contrapone con el del basilisco- es en el cristianismo la equivalencia de Cristo al proclamarse en las escrituras del Evangelio como "luz del mundo".

En el segundo panel los motivos animales reproducidos son el elefante y la ardilla, con significado opuesto. El elefante tiene un valor positivo para la religión cristiana: se asimila a virtudes como la templanza, fuerza y mansedumbre y sobre todo se identifica con la castidad, pudiendo simbolizar a Adán y Eva, antes del pecado original. En contraposición, la ardilla es relacionada con el símbolo del demonio y del mal en general. En el tercer panel, en su costado izquierdo, se disponen entre la rocalla las figuras de un ave, que podría ser el pelícano por su largo pico y una serpiente. El primero de estos dos motivos animales ha estado siempre vinculado al mundo cristológico como lo reflejan los bestiarios medievales. El pelícano se hiere y ofrece su

${ }^{88} \mathrm{M}^{\mathrm{a}}$ D. C. MORALES MUÑIZ, «El simbolismo animal en la cultura medieval», en Espacio, Tiempo y Forma, $H^{a}$ Medieval. T.9, Madrid, 1996, pp. 229-255.

${ }^{89}$ En la simbología cristiana medieval el basilisco es una de las cuatro bestias malignas que aplasta Cristo (junto al áspid, león y dragón) y es representación del pecado y de la muerte. 
sangre a sus polluelos para alimentarlos y salvarlos de la muerte, como Jesucristo hará con su sangre por los pecados de los hombres. La serpiente es un reptil que en la religión cristiana tiene un carácter sumamente negativo. Se asocia al recuerdo del pecado original y, como tal, también está relacionada directamente con la redención del hombre gracias a la muerte y resurrección de Jesucristo.

El costado derecho del cuarto panel nos descubre dos figuras animales: un ave de pequeño tamaño picoteando el suelo que identificamos con la perdiz y un gran pez que vierte agua, que podría identificarse con un delfín, a pesar de su extraña forma. La perdiz es un animal considerado en una de las acepciones significativas de la tradición cristiana con un simbolismo negativo, asimilado a la tentación. Por el contrario, el delfín presenta para los cristianos un valor positivo al asimilarse con la representación de Cristo y generalmente con el símbolo del ancla, metáfora de la cruz. El último de los paneles vuelve a incidir en el uso de los animales con una finalidad religiosa y moral. En los laterales se tallan las figuras de una lechuza y una abubilla, y en la parte superior la imagen de un simio que porta un arma. La lechuza, ave de la noche, es un animal de significado polisémico ${ }^{90}$. Para el cristianismo representa a Jesucristo en la noche del sufrimiento y de la muerte. La abubilla, también ave con un simbolismo plural en las diferentes culturas, se relaciona en la doctrina cristina con los pecadores que de forma reiterada se regodean en la suciedad del pecado. Este sentimiento del pecado queda reforzado en la figura del mono cazador, símbolo del demonio que atrapa al ser humano "causando su perdición en el cuerpo y el alma". La figura central de la cajonería, sobre la que girará todo

${ }^{90}$ H. BierdeEmann, Diccionario de símbolos; Editorial Paidós, Barcelona, 2009, p. 262. el significado de los respaldos, es Cristo representado en la escena de la crucifixión y a través del relieve de la Verónica que porta el paño con su efigie. Esta última escena nos acerca la imagen de Cristo, desfigurado por la maldad humana, y expresión de su amor hacia los hombres, de la misericordia infinita de Dios Padre, que entrega a su hijo, divino Salvador ${ }^{91}$.

\section{FRAY JOSÉ DE SAN JUAN DE LA CRUZ GRABADOR}

Dentro de las actividades menos conocidas practicadas por este carmelita, hay que señalar su trabajo como autor de estampas devocionales, labor que suscitó las más airadas protestas de José Bejes. Dicho artista criticó en el Memorial conservado en la Real Academia de Bellas Artes de San Fernando la escasa preparación técnica del lego carmelita en este arte, mostrando para ello una de sus obras y asimismo su voracidad en los contratos apropiándose de proyectos ajenos.

Así lo subraya en relación con una estampa de Nuestra Señora de la Soledad que deseaba realizar el comendador del convento de Nuestra Señora de la Merced de Logroño. José Bejes, que había realizado varias pinturas para dicha fundación, le ofrecerá su colaboración al comendador ejecutando el diseño de la futura estampa y buscando posteriormente un grabador experto en Madrid ${ }^{92}$ que llevase a buen puerto la obra. Sin embargo, Fray José de San Juan de la Cruz se adelantaría a la actuación del pintor nacido en Potes, ejecutando el gra-

\footnotetext{
${ }^{91}$ Esta consideración de Cristo como divino Salvador puede estar reforzada por la disposición sobre el relieve de la Verónica de un sol entre nubes.

92 Entre los principales grabadores radicados en la corte destaca Juan Bernabé Palomino (1692-1777) y Manuel Salvador Carmona (1734-1820), que fueron directores de grabado de la Real Academia de Bellas Artes de San Fernando.
} 
bado ante la sorpresa e indignación de Bejes quien también denunció el elevado coste de la lámina ${ }^{93}$.

La actuación de Fray José como grabador venía ya de antiguo. José Manuel Ramírez Martínez ${ }^{94}$ señala que en 5 de mayo de 1745 había entregado en la villa riojana de Ocón una lámina para fabricar estampas de santos realizada en el convento de Villafranca, donde profesaba, por 510 reales. Además subrayaba que él mismo se haría cargo de fabricar un pequeño tórculo para imprimir las estampas.

La formación de este carmelita como grabador debió forjarse en el seno de la propia orden del Carmelo en conexión muy probablemente con Fray José de los Santos. Pedro Luis Echeverría Goñi y Ricardo Fernández Gracia ${ }^{95}$ documentan un grabado realizado en 1748 por este padre firmado como "Fray Joseph me fecit" con el motivo de Fray Juan de Jesús orando arrodillado ante un grupo escultórico de San Joaquín y la Virgen Niña, que se encuentra en el convento de los padres Carmelitas de Pamplona, lo que evidencia la dedicación de este carmelita al arte del grabado.

La faceta como grabador de Fray José de San Juan de la Cruz ha sido hasta el momento deficientemente conocida. El legado de estampas grabadas pertenecien-

93 ...quando dentro de pocos dias bienen y me dizen que el fraile del Carmen esta abriendo la chapa callé, dexé que saliera a lud y executó la estampa adjunta para que se aga presente en esa Aca. ${ }^{\text {mia }}$ que discurro dará golpe, su coste a sido 600 rs bien entendido que los persuadió a que solo llebaba la metad de su justo precio (ARASF 2-24-7).

94 J. M. RAmírez MARTíNEZ, Retablos mayores de La Rioja; Obispado de Calahorra y La Calzada, Agoncillo, 1993, p. 70.

95 P. L. ECHEVERRÍA GOÑI y R. FERNÁNDEZ GRACIA, «El convento e iglesia de los Carmelitas Descalzos de Pamplona. Exorno artístico», en Revista Príncipe de Viana Año 42, № 164, IV Centenario de la muerte de Santa Teresa, Pamplona, 1981, p. 856. tes a Antonio Correa Ruiz (Manila, 1923Comillas, 2008) ${ }^{96}$, depositado en la Calcografía Nacional, contiene dos obras del lego carmelita: un grabado de San Saturio, fechado en 1751, y otra lámina que representa San Juan de la Cruz. Asimismo, dicho catálogo señala la autoría de Fray José de San Juan de la Cruz respecto al grabado anteriormente citado de Fray Juan de Jesús que como sabemos no llevó a cabo ${ }^{97}$. A estas dos láminas devocionales hay que unir hoy la lámina grabada de Nuestra Señora de la Soledad, ya citada, inclusa en el Memorial de Bejes.

La información que presenta la catalogación del fondo de Antonio Correa, incorpora un dato novedoso por lo que respecta a la biografía de Fray José que conocemos, y que a día de hoy no hemos podido verificar documentalmente: su presencia en tierras segovianas en la segunda mitad del siglo XVIII ${ }^{98}$. Ignoramos si esta afirmación tiene algún referente informativo concreto, o tan sólo deriva de una relación establecida por el autor de la catalogación con el texto de la estampa de San Juan de la Cruz que cita la indulgencia concedida por el obispo de Segovia para quienes rezaren ante ella.

La difusión de la estampa devocional fue muy importante en España durante los siglos XVII y XVIII99. La estampa religiosa

${ }^{96}$ J. M. MATILLA, «Antonio Correa. La pasión por coleccionar», en Grabado y edición, № 10, septiembre de 2007, pp. 6-13.

${ }^{97}$ Calcografía Nacional. Archivo Antonio Correa. (AC 14387. Caja 49).

${ }^{98}$ En el catálogo del legado de Antonio Correa se indica que estuvo activo en Segovia en la segunda mitad del siglo XVIII.

${ }^{99}$ J. PORTÚs y J. VEGA, La estampa religiosa en España del Antiguo Régimen; Madrid, 1999 y R. FERNÁNDEZ GRACIA, Estampa, Contrarreforma y Carmelo Teresiano. La colección de grabados de las Carmelitas Descalzas de Pamplona y Leonor de la Misericordia (Ayanz y Beaumont); 
fue desde el primer momento vehículo de divulgación de importantes devociones (Cristos, Vírgenes, santos), potenciándose la fe del pueblo y sus emociones piadosas, y asimismo posibilitando la creación de una cultura visual en la sociedad en los distintos grupos sociales ${ }^{100}$. Las estampas, a la vez que presentaron un carácter decorativo, sirvieron como imagen de veneración con el mismo valor que podían tener las imágenes talladas y las pinturas sobre lienzo.

Las características estilísticas de las estampas religiosas en España durante la segunda mitad del siglo XVIII se basan en una estética, de raigambre rococó (inserción de las imágenes en altares poblados de rocalla, dibujo de cartelas con guirnaldas de flores y rocallas, etc.) frente a otras que ya se asimilan al Neoclasicismo. Desde el campo de la técnica se observan algunas obras que siguen el procedimiento del grabado sobre madera, frente a la calcografía, a la que se adscribe la obra de este religioso, que emplea la técnica de la talla dulce, muy extendida a lo largo de los siglos barrocos, trabajando con buril sobre una plancha de cobre, dejando surcos o tallas de diferente profundidad y forma con las que se crea la composición del grabado.

La primera de las obras que analizaremos es una estampa de San Saturio ${ }^{101}$, famoso anacoreta cuya vida transcurrió en la ciudad de Soria entre los años 493 y 570 aproximadamente, siendo proclamado patrón de ella el año 1628. Mide 217 x 142 $\mathrm{mm}$, está fechada en 1751 y firmada por el

Imprenta Gráficas Castuela, Pamplona, 2004.

100 J. CARRETE PARRONDO, «Arte y devoción», en Arte y devoción. Estampas de imágenes y retablos de los siglos XVII y XVIII en iglesias madrileñas; Ayuntamiento de Madrid y Calcografía Nacional, Madrid, 1990.

101 Calcografía Nacional. Archivo Antonio Correa. AC 14386. Caja 49. Con fecha de 1768 está documentada en esta colección otra estampa de San Saturio, obra de un grabador apellidado Ribapalacio. autor como "Fr. Josephus $\hat{a} S^{\text {to }}$ Joanne â Cruze $f(e) c(i) t^{\prime \prime}$. Fue costeada por don Francisco Pérez Uclés, prebendado de la Colegiata de San Pedro en Soria, como subraya el texto inferior. El grabado realizado según la técnica calcográfica de la talla dulce, reproduce el expositor y busto relicario del santo fabricado en el siglo XVII ${ }^{102}$ que se exhibe en el retablo de su ermita soriana. El busto relicario se halla dispuesto en el centro de un arco lignario, recubierto por decoración floral que remata en el escudo de la ciudad de Soria (compuesto por un castillo con tres torres almenadas y un busto saliente masculino), flanqueado por dos ángeles. Todo el grabado muestra la destreza del hermano lego carmelita en la ejecución del dibujo de los elementos del retablo barroco, así como en la propia imagen relicario del santo, destacando el detallismo en el tratamiento del rostro y capa que cubre la arqueta propiamente dicha. Aparejadas a estas características debemos resaltar una vez más el sentido ornamental propio del autor que exhibe la lámina.

La segunda estampa de Fray José representa a San Juan de la Cruz orando en la cueva o gruta que hay en las Peñas Grajeras en la que los carmelitas descalzos establecieron su fundación y en el que Juan de Yepes fue nombrado prior en $1588^{103}$. El grabado $^{104}$, sin fecha, mide $213 \times 154 \mathrm{~mm}$, y

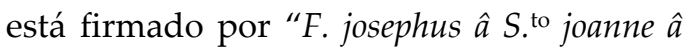
Cruze C.ta" que aparece como autor del diseño, ejecutor del dibujo sobre la plancha y también como grabador. El análisis técnico muestra el uso de la técnica calcográfica

102 S. AlCOLEA, Soria y su provincia; Editorial Aries (Colección Guías artísticas de España № 29), Barcelona, 1964, p. 57.

103 P. A. DE SAN JuAN DE LA CRUz O.C.D., El Carmelo en Segovia. San Juan de la Cruz en Segovia, Segovia, 19 de marzo de 2001.

104 Calcografía Nacional. Archivo Antonio Correa. AC 8872. Caja 44. 
de la talla dulce. Fray José perfila con precisión los motivos de la lámina, tallando con diferente profundidad algunos de ellos para favorecer una gama distinta de negros y grises tras el entintado de la plancha. El estilo muestra el sentido ornamental que aparece en toda su producción, acercándonos a la estética que presentan los diseños de sus paisajes en retablos, cajonerías y relieves de estuco, con numerosos elementos arquitectónicos ${ }^{105}$, florales y animales que también están presentes en la estampa. La cartela inferior muestra, una vez más un gusto decorativo que nos aproxima a la estética rococó. La estampa muestra con vocación escultórica a San Juan de la Cruz, en posición arrodillada en la gruta, escribiendo con una pluma la obra Llama de amor viva ${ }^{106}$. El santo recibe la inspiración luminosa de la paloma del Espíritu Santo, cuyo rayo potente refulge sobre la cabeza rodeada por un nimbo solar, y se traspasa al libro y fundación carmelitana. Sobre esta escena central el carmelita dibujó dos ángeles que sostienen una cinta o filacteria, en cuyo interior se dispuso un texto relativo al suceso que recrea la lámina ${ }^{107}$. Se trata de una escena de milagro, de una escena de revelación divina muy al gusto de la iconografía

\footnotetext{
105 La imagen de la iglesia conventual con torre enchapitelada y cúpula, a la moda de la arquitectura barroca castiza española del siglo XVIII, recuerda algunos modelos que aparecen en los paisajes de las cajonerías de las sacristías de la Catedral de Burgos y Santo Tomás de Haro.

${ }^{106}$ La composición poética y la exposición debieron ser compuestas entre 1584 y 1586 en los Mártires de Granada a requerimiento de la segoviana Doña Ana de Peñalosa. Junto con su hermano Luis de Peñalosa fue benefactora de la fundación de los carmelitas descalzos en Segovia, utilizando para ello el legado testamentario de su esposo don Juan de Guevara, que había ocupado un destacado cargo en la Chancillería de Granada.

107 Puntual diseño del extatico y cherubico Doctor S. Juan de la Cruz en la cueva de la huerta de su Colegio de Segovia, siendo Presidente de la Consulta ô Difinitorio y Prior del mismo Colegio.
}

del barroco inserta en un paisaje rocoso que recuerda el de las Peñas Grajeras segovianas al que se retiraba a orar y el entorno físico en que imagina que se desarrollan los versos de las Canciones entre el alma y el Esposo rodeado por una densa vegetación, aves y otros animales que circulan por el monte ${ }^{108}$.

Fray José reproduce la efigie del santo carmelita nacido en Fontiveros con los rasgos habituales que le identifican: enjuto y semicalvo, vestido con túnica y muceta con capucha y sandalias en los pies. El lego carmelita quiso además dejar patente el sentido místico que prende en la figura del santo a través de la mirada en éxtasis, y la posición de brazos y manos extendidos, potenciando el valor comunicativo y significativo de la estampa. El grabado muestra en su parte inferior una cartela de notable importancia que incorpora en su frente superior dos tercetos octosílabos encadenados, que muy probablemente se deban a la propia pluma de Fray José, poblados de motivos iconográficos que se contemplan en el grabado ${ }^{109}$.

Bajo estas dos estrofas la cartela muestra un texto en el que se anuncia que el obispo de Segovia don Diego de Medrano concedía 40 días de indulgencia a quienes rezaren ante esta estampa las oraciones del Padre Nuestro y el Avemaría. Esta conducta ejemplifica el valor dado a la estampa religiosa en promoción de la piedad y devoción en los fieles, que reciben beneficios religiosos mediante la oración ante grabados de Cristo, de la Virgen y de santos ${ }^{110}$. El texto de la cartela presenta además

108 C. DE JESÚs O.C.D., Vida y obras completas de San Juan de la Cruz; Editorial B.A.C., 6 ${ }^{\mathrm{a}}$ ed., 1972, p. 403.

${ }^{109}$ La paloma del Jordán/ vibra luz a todas oras/ en los cristales de Juan/ Ángeles, aves cantoras/ dulce música le dan/ en melodías sonoras.

${ }^{110}$ J. PORTÚs y J. VEGA, La estampa religiosa en Es- 
un notable interés para nuestra investigación, pues nos permite establecer una cronología aproximada para la realización de esta obra a través de la cita referente al obispo, que gobernó la diócesis de Segovia entre 1742 y $1752^{111}$. Sin embargo, desconocemos qué circunstancias motivaron la realización de la estampa, y el lugar de ejecución de la misma, ignorándose si el fraile arquitecto carmelita residió durante alguna etapa de su vida en la fundación de Segovia.

La tercera de las estampas de este fraile corresponde a la plancha de la Virgen de la Soledad que realizó para el convento de Nuestra Señora de la Merced de Logro$\tilde{n} 0^{112}$. La imagen de la Virgen de la Soledad era santo y seña de una cofradía que nació amparada en este convento y de la que conservan datos relativos a la celebración de su fiesta en 1638. Dicha cofradía estaba ya consolidada en 1684, fecha en que adquiere una capilla propia en dicha fundación, donde se veneraba la escultura titular de la cofradía. Desconocemos el paradero de dicha talla, que abandonaría el convento

paña del Antiguo Régimen; Madrid, 1999, pp. 314-316.

111 Don Diego García de Medrano, era natural de Robledo de Chavela. Eclesiástico de gran valía, fue párroco en la iglesia de La Asunción de Pozuelo en la provincia de Madrid. Adepto a la Ilustración, participó a lo largo de su vida en diversas empresas de hondo calado en la sociedad española del siglo XVIII como la reforma de la Universidad de Alcalá de Henares y el Montepío de las Descalzas Reales. Siendo obispo de Segovia convocó un sínodo orientado a devolver a la iglesia segoviana una espiritualidad verdadera y sencilla. Además de su importante papel religioso destacó también su labor como promotor artístico tanto en su localidad natal, como en los lugares en que sirvió.

112 El convento de los mercedarios es hoy sede de la Biblioteca Central de La Rioja, de una sala de exposiciones y del Parlamento de la Rioja, habiendo albergado también una fábrica de tabacos a fines del siglo XIX. Del primitivo convento se conserva la iglesia que muestra un tabernáculo barroco, sillería de coro y diversas piezas de orfebrería. de la Merced tras la Desamortización de Mendizábal. Como se indica en el extremo inferior derecho de la estampa, fue grabada en el convento del Carmen de Logroño, residencia del arquitecto carmelita. Técnicamente la lámina responde a las características de las otras dos anteriormente descritas. Está grabada con la técnica de la talla dulce, utilizando el buril sobre la plancha metálica. Destaca en ella la corrección del dibujo y la gradación de negros y grises conseguida a través del entrecruzado de surcos en la plancha por el buril.

El diseño de la misma se adscribe a la estética rococó, que impera en el diseño del retablo en que se coloca la figura de la Virgen de la Soledad, que recuerda sus diseños para la iglesia de Santa María de Viana. Se trata de una arquitectura con un sólo vano de medio punto que se apoya en unas pilastras ornadas con motivos de la pasión (clavos, martillo, tenazas) engarzados por un lazo, al modo que ya hemos visto en algunos relieves de la cajonería de la iglesia de Santo Tomás de Haro, y con dos ángeles dispuestos en su parte inferior sobre dos volutas. Los dos laterales del retablo aparecen decorados con diferentes motivos arquitectónicos recubiertos por rocalla. En el remate del retablo Fray José ideó una estructura de frontón partido muy borrominesco flanqueado por las figuras de dos ángeles en actitud de lamento y rocallas, disponiendo en el interior del mismo un corazón atravesado por espada, símbolo de la Virgen de la Soledad.

La Virgen de la Soledad, culto de gran arraigo en La Rioja ${ }^{113}$, está representa-

${ }^{113}$ Así lo demuestran las destacadas imágenes de la Iglesia de Santa María La Redonda de Logroño, donada por el capitán Gabriel de Unsain en 1694, de la parroquia de Cornago y de la parroquial de Huércanos, escultura esta última que fue reformada por Pedro Busou del Rey, escultor de cámara del Infante don Gabriel de Borbón. 
da según la iconografía usual ${ }^{114}$ : lleva corona con rayos y estrellas en sus puntas, viste con un manto negro, sayal blanco y lleva rostrillo, según la moda de los siglos XVII y XVIII. Sobre las vestiduras, que muy probablemente cubran una armazón de madera, destaca la disposición de un rosario y un corazón al que atraviesan siete espadas, motivo iconográfico que alude una vez más al sufrimiento y pasión de María. La figura de la Virgen presenta un sentido teatral propio de la imaginería barroca, acentuando el dramatismo el movimiento de las manos y la triste expresividad del rostro. La estampa se completa, como es usual en otras coetáneas ${ }^{115}$, con una cartela que lleva el escudo de los padres mercedarios y en su interior un texto escrito. En él se señala que el grabado es un retrato verdadero de la imagen de la Virgen de la Soledad, venerada en una capilla del convento de la Merced de Logroño. Asimismo se indica que la lámina fue costeada por fieles devotos.

\section{CONCLUSIONES}

El Memorial por Bejes ante la Real Academia prueba, de forma clara, el desencuentro entre este maestro y Fray José. El texto de recriminación contra el fraile está adornado, siempre, de un intento de de defensa del "buen gusto" que la Real Academia de San Fernando estaba intentando de imponer en el desarrollo de las artes hispánicas desde su fundación. Sin embargo, como hemos señalado, ni el pintor Bejes ni el ensamblador Portu habían tenido nin-

114 Así lo reflejan otras imágenes de la Soledad conservadas en el corpus de estampas de la colección de Antonio Correa.

115 Estos mismos rasgos presentan dos estampas grabadas de la época presentes en la colección de Antonio Correa: una estampa de la Virgen Aparecida, de Manuel Virués y Campaña (1777) y el grabado de la Virgen del Cubillo realizado por Ventura de Noreda en 1780. gún problema en colaborar con el carmelita en diversas actuaciones artísticas en los años inmediatamente anteriores. Por otro lado, aunque es cierto que el pintor de Potes tenía, al parecer, un amplio recorrido internacional, su obra se halla inscrita en unos parámetros estéticos más próximos al Barroco exaltado que al Barroco Clasicista que, en estos momentos, se estaba imponiendo en el arte español por Mengs y sus seguidores. Lo mismo podemos decir con respecto a Portu y a su actividad retablística. Probablemente, en un momento de sus dilatadas carreras, lo que en principio fue una relación de colaboración y apoyo mutuo acabó trastocándose en un enfrentamiento evidente, lo cual acontecería, con toda seguridad, a raíz de algún roce por el control de alguna obra, más teniendo en cuenta la versatilidad de Fray José. Fue esta la razón que llevaría a Bejes a dirigirse a la Academia, aprovechando los vientos que comenzaban a soplar en sentido contrario al Barroco tradicional, intentando tanto él como Portu "reinventarse" estéticamente. Bejes se subiría al carro de las críticas de Ponz quien pronunció la famosa frase, refiriéndose a Fray José, de que un profesor de mucho mérito, que actualmente vive, dijo cuando, pasando por Burgos, vio esta obra, que se podía dar por deshacerla tanto como costó hacer, y soy de su opinión. Creemos que este profesor, al que cita Ponz fue Roberto Michel, pues Bejes también habla de él en el Memorial como detractor del carmelita. Sabemos que Michel había colaborado en el exorno del santuario de San Gregorio Ostiense, erigido conforme a la traza del carmelita, pues allí se colocaron distintas esculturas de este maestro cortesano en $1768^{116}$. Quizá, en el proceso de ornamentación escultórica de este santuario hubo discrepancias entre

116 R. FERNÁNDEZ GRACIA, «Reflexiones sobre el arte foráneo en Navarra durante los siglos del Barroco», Cuadernos de la Cátedra de Arte y Patrimonio, № 3, 2008, pp. 295-359. 
Michel y Fray José que generaron un enfrentamiento notable entre este escultor emergente y cada vez más poderoso en el ámbito cortesano y el lego carmelita que co-

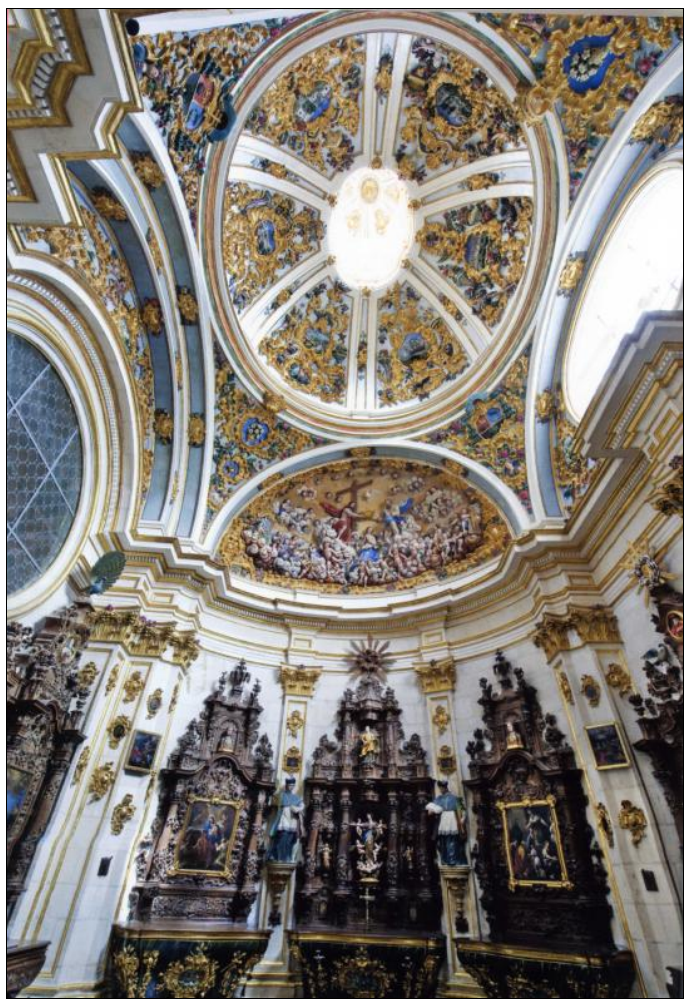

- Fig. 1. Fray José de San Juan de la Cruz. Sacristía de la Catedral de Burgos. comenzaba a ver cómo el mundo de los valores estéticos y de las relaciones entre artistas y clientes en el Antiguo Régimen comenzaba, poco a poco, a desmoronarse.

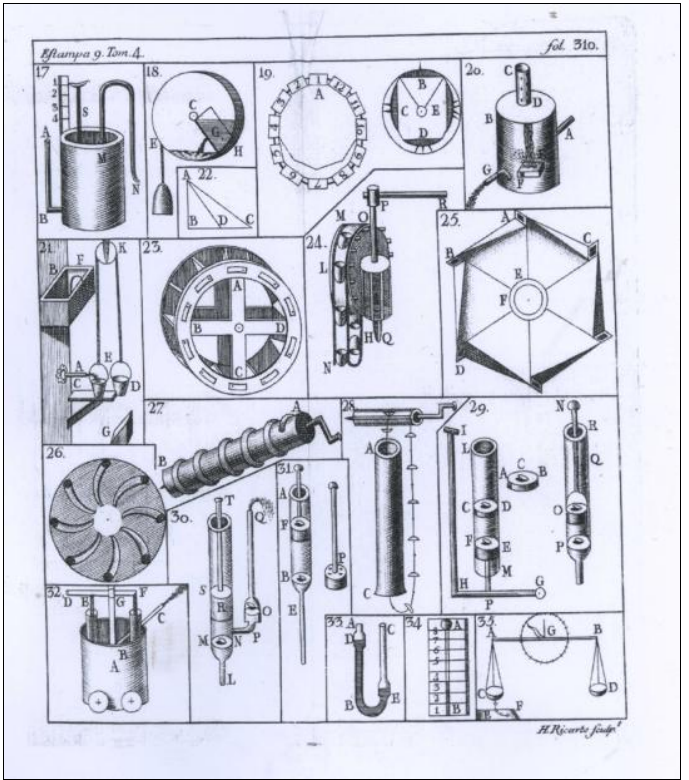

- Fig. 2. Ingenio para sacar agua. P. Vicente Tosca.

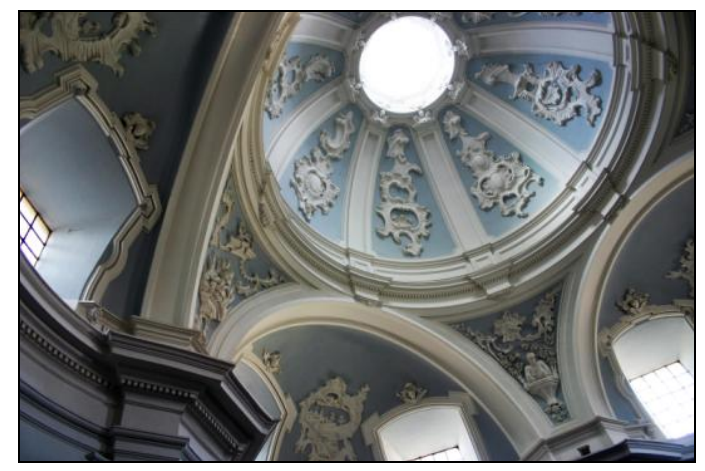

- Fig. 3. Fray José de San Juan de la Cruz. Bóveda de la sacristía de la iglesia de Santo Tomás de Haro. 


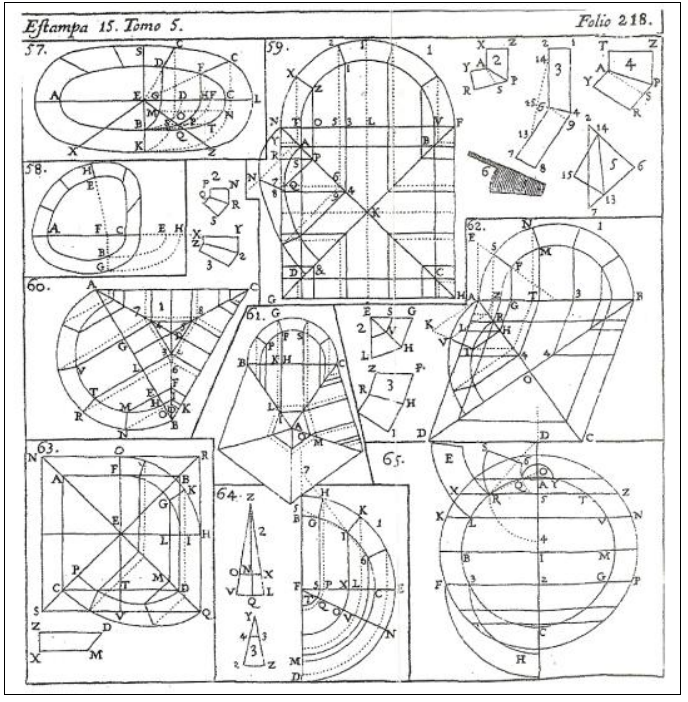

- Fig. 4. Propuestas de cortes de bóvedas de Tomás Tosca.

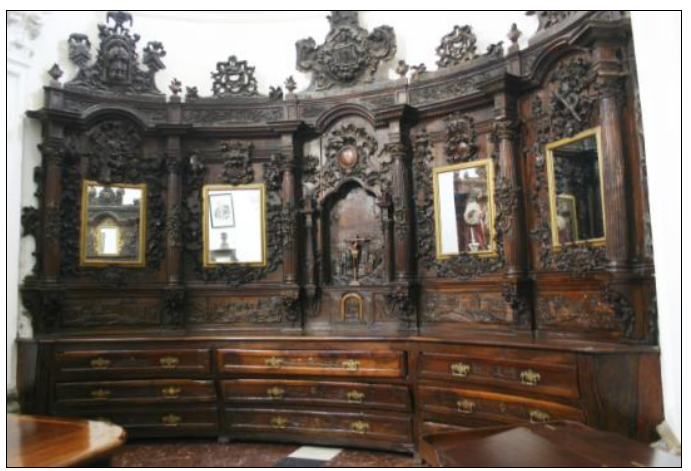

- Fig. 6. Fray José de San Juan de la Cruz. Cajonería de la sacristía de la iglesia de Santo Tomás de Haro.

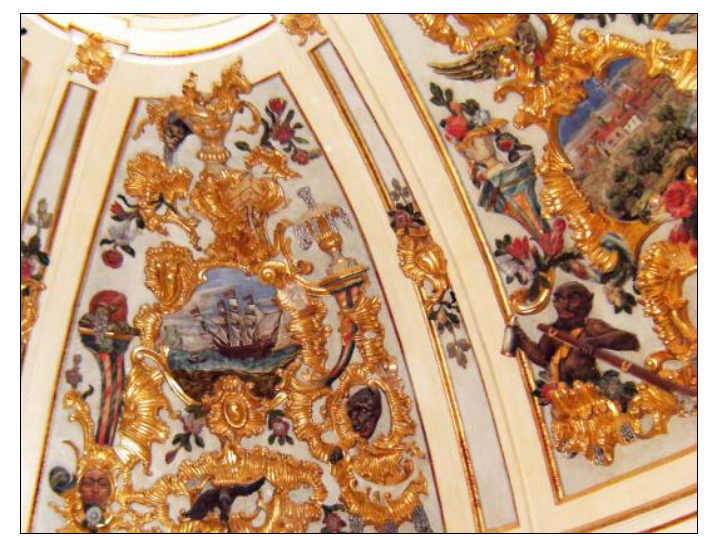

- Fig. 8. Fray José de San Juan de la Cruz. Detalle de la yesería de la sacristía de la Catedral de Burgos con la figura del mono cazador.

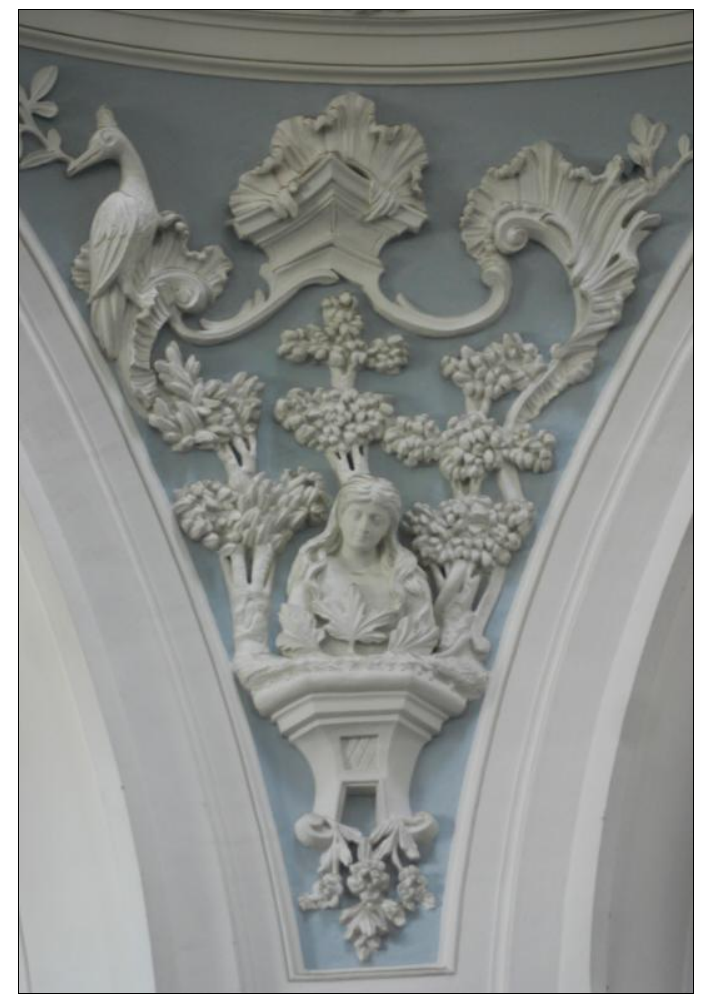

- Fig. 5. Fray José de San Juan de la Cruz. Yeserías de la bóveda de la sacristía de la iglesia de Santo Tomás de Haro.

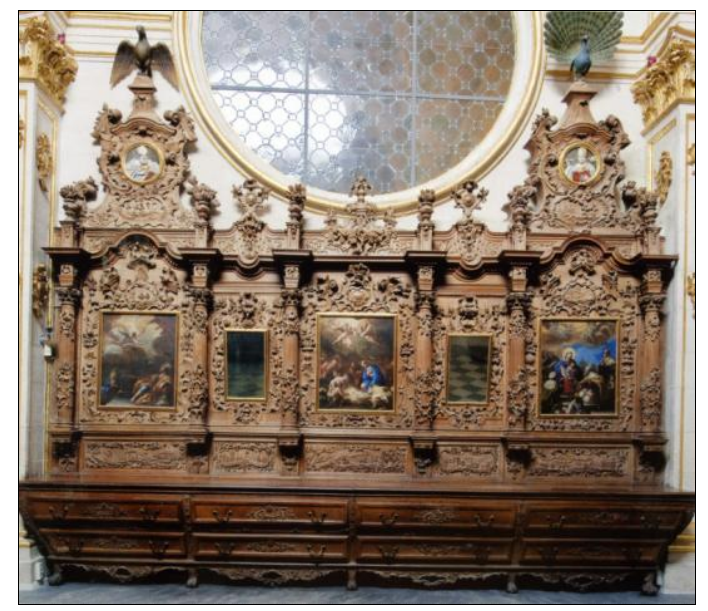

- Fig. 7. Fray José de San Juan de la Cruz. Cajonería de la sacristía de la Catedral de Burgos. 


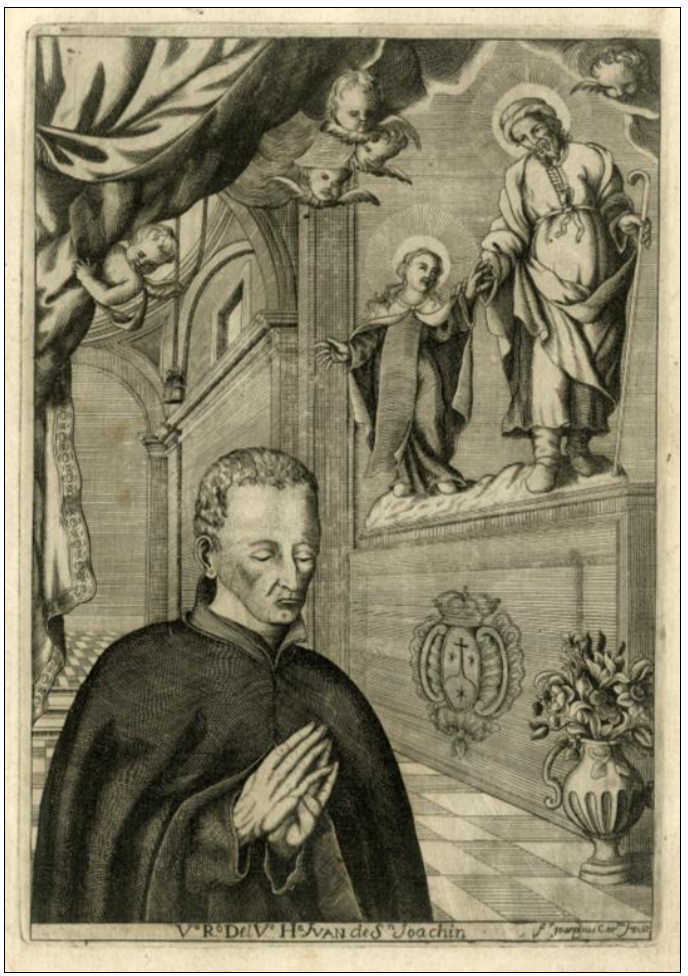

- Fig. 9. Fray José de los Santos. Fray Juan de San Jesús rezando ante San José.

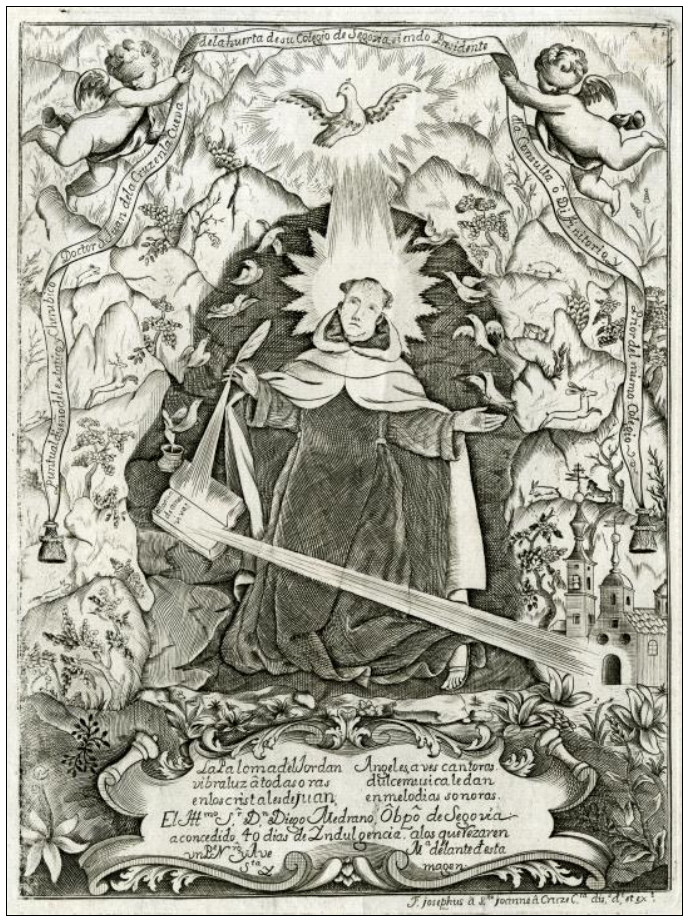

- Fig. 11. Fray José de San Juan de la Cruz. San Juan de la Cruz.

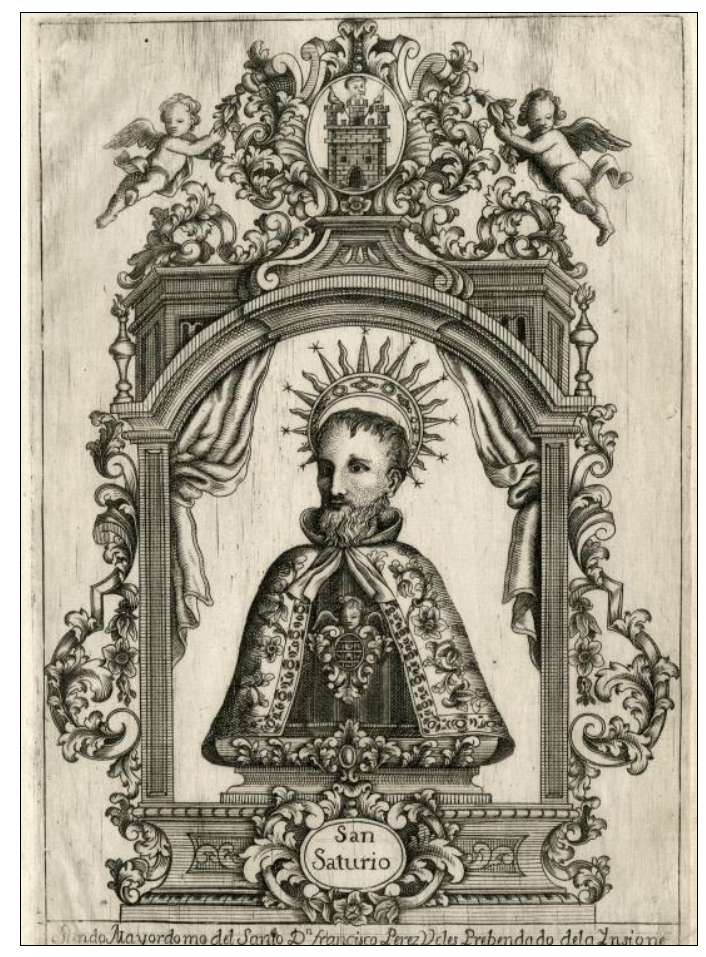

- Fig. 10. Fray José de San Juan de la Cruz. San Saturio. 1751.

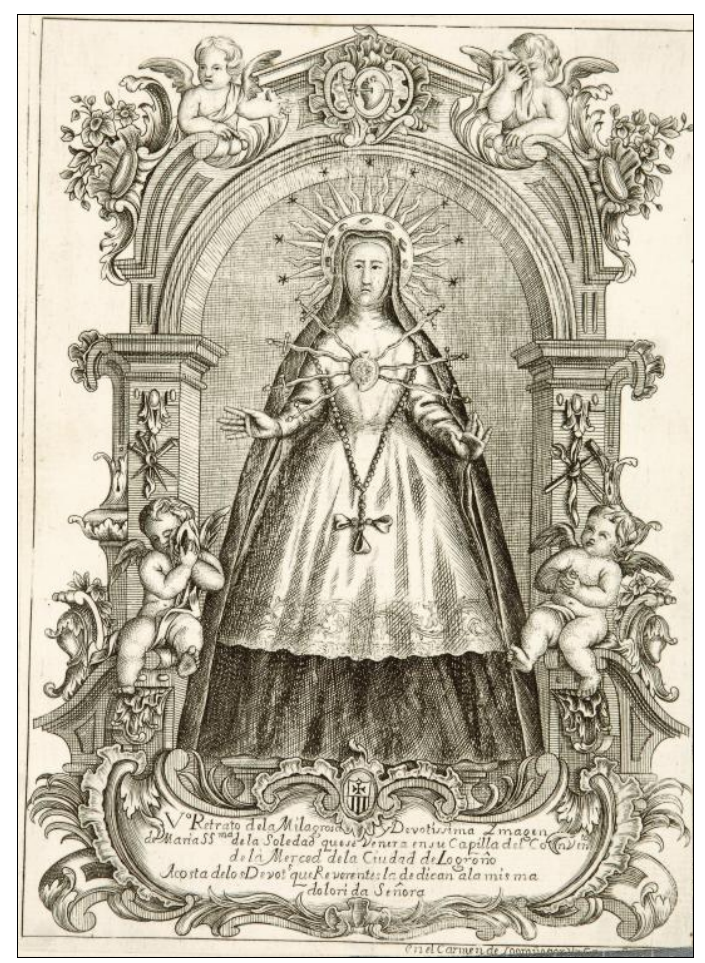

- Fig. 12. Fray José de San Juan de la Cruz. Nuestra Señora de la Soledad del Convento de la Merced de Logroño. 